\title{
NONPECUNIARY CLASS ACTION SETTLEMENTS
}

\author{
GeOffrey P. MILLER*AND LORIS. SINGER** \\ INTRODUCTION
}

There has been an upsurge of interest in class action litigation over the past few years. Legal scholars, ${ }^{1}$ journalists, ${ }^{2}$ and politicians ${ }^{3}$ have all weighed in on the topic. Congress reformed federal securities class action procedures in $1995,{ }^{4}$ and an advisory committee is weighing a proposal for fundamental changes to R ule 23 , the general federal class action provision. ${ }^{5}$ The Supreme Court of the $U$ nited States issued important decisions on class action settlements during the past few years, ${ }^{6}$ and more are likely to follow.

\footnotetext{
Copyright (C) 1997 by L aw and Contemporary Problems

This article is also available at http://www.law.duke.edu/journals/lcp.

* Professor of L aw, N ew Y ork U niversity.

** M ember of the Illinois B ar; J .D. 1996, U niversity of Chicago.
}

We would like to thank Steven A rmstrong, J ohn Bailey, Todd Kornfeld, J acqueline C. M aduneme for research assistance, E dward $\mathrm{H}$. Cooper, Clinton K rislov, J effrey Lennard, Thomas $\mathrm{M}$ eites, $\mathrm{R}$ andall Thomas, G reg Sergienko, G erald W etlaufer, and participants at a U niversity of I owa faculty workshop for providing helpful background and comments, and Dean John Sexton for his encouragement and support throughout.

1. See sources infra notes 12-18.

2. See, e.g., B arry M eier, Fistfuls of Coupons, N.Y. TIMES, M ay 26, 1995, at D 2 (plaintiffs in corporate class action suits increasingly being paid with scrip while their attorneys walk away with millions in cash); R ichard B. Schmitt, The D eal M akers: Some Firms E mbrace the Widely D readed ClassA ction L awsuit, W A LL ST. J., J uly 18, 1996, at A 1 (some corporations welcome class action lawsuits as a means for preventing people from suing in the future); R ichard B. Schmitt, O bjecting to Class-A ction Pacts can be L ucrative for A ttorneys, W A LL ST. . ., J an. 10, 1997, at B 1 (law firms are earning large fees from objecting to class action settlements); Mike Tolson, Attorney Fees: How Much is Too Much?, H OU STON CHRON., O ct. 21, 1996, at 13 (attorney proposes to take a $\$ 109$ million fee out of $\$ 170$ million settlement); see also KURT EICHENWALD, SERPENT ON THE R OCK (1995) (detailing how a brokerage firm defrauded innocent investors of billions of dollars and landed in a massive class action lawsuit).

3. See, e.g., NeWT GINGRICH ET AL., CONTRACT WITH A MERICA 147-54 (1994) (criticizing attorney control of litigation process in class action and other cases); A buse of A ttorneys Fees in $M$ ass Torts, Subcomm. on O versight and Investigations of the Senate J udiciary Committee, 105th Cong. (1997); Product L iability R eform and How the L egal Fee Structure A ffects Consumer Compensation: Hearings B efore the Subcomm. on Telecommunications, Trade, and Consumer Protection of the H ouse Committee on Commerce, 105th Cong. (1997).

4. See Private Securities L itigation R eform A ct of 1995, Pub. L. N 0. 104-67, 109 Stat. 737 (1995).

5. See, e.g., Proposed A mendments to the Federal Rules of Civil Procedure, Rule 23, Class A ctions, reprinted in 167 F.R.D. 559 (1996).

6. See A mchem Products, Inc. v. Windsor, 117 S. Ct. 2231 (1997); M atsushita E lec. Ind. Co., L td. v. Epstein, 116 S. Ct. 873 (1996). 
The class action procedure serves a number of objectives: It conserves social resources by consolidating many similar cases in a single proceeding, enables persons with small claims to obtain a hearing on their grievances that would otherwise not be economically feasible, and facilitates compensation for large numbers of injured persons. ${ }^{7}$ Class actions also serve deterrent purposes. If a company can anticipate becoming a defendant in a class action lawsuit when it violates the rights of large numbers of people, then it is less likely to engage in wrongful behavior.

Despite these benefits, critics of the process charge that class suits often take the form of meritless nuisance litigation filed solely to obtain a settlement offer, ${ }^{9}$ and that such suits are brought by plaintiffs attorneys whose primary motive is to settle the case for a high fee, even at the class's expense. C ritics direct some of their harshest criticism at so-called coupon settlements, which give class members the right to purchase additional goods or services from the defendant while plaintiffs' attorneys receive multimillion dollar fees. ${ }^{10}$ The coupon settlement is one species of a broader category of nonpecuniary class action settlements — settlements in which consideration other than an immediate cash payment is given to class members in exchange for a release of legal claims against the defendant.

In this article, we provide a theoretical and empirical analysis of nonpecuniary class action settlements. O ur goal is to replace some of the recent hysteria about coupon and other nonpecuniary settlements with a more balanced account that identifies the benefits, as well as the costs, of such agreements.

First, we develop a typology of nonpecuniary settlements, and describe in detail each of five types. In addition to coupons, nonpecuniary settlements include distributions of securities, monitoring for future harm, reverter funds in which unclaimed settlement funds return to the defendant, and fluid recovery

7. See Geoffrey P. Miller, Class Actions, in New Palgrave Dictionary of LaW \& ECONOMICS (Peter N ewman ed., forthcoming 1998).

8. See, e.g., K enneth W. Dam, Class Actions: Efficiency, Compensation, D eterrence and Conflict of Interest, 4 J . LE GA L STU D. 47, 54-56 (1975).

9. See, e.g., Claudia M acL achlan, M eritless Class Suits: A N ew Focus, N A T'L. L J ., A ug. 5, 1996, at A 9. On nuisance suits, see, for example, Lucian B ebchuk, A New Theory Concerning the Credibility and Success of Threats to Sue, 25 J. LEGA L STUD. 1 (1996); R obert B one, M odeling Frivolous Suits, 145 U. PA . L. REV. 519 (1997); A very K atz, The E ffect of Frivolous L awsuits on the Settlement of L itigation, 10 INT'L REV. L. \& E CON. 3 (1990); D avid R osenberg \& Steven Shavell, A M odel in Which Suits A re Brought for Their Nuisance V alue, 5 INT'L REV. L. \& E CON. 3 (1985).

10. See, e.g., R obert $M$ auk, $L$ awsuit $A$ buse: $P$ ublic's W elfare $H$ urt When $L$ awyers $H$ elp Themselves, CHARLESTON GAZETTE, A pr. 28, 1997, at A 5 (criticizing coupon settlements as unfair to class members). Perhaps the best known coupon settlement is In re $\mathrm{G}$ eneral M otors Corporation Pickup Truck Fuel Tank Products L iability Litigation, 55 F.3d 768 (3d Cir. 1995) and the companion case, General M otors v. B loyed, 916 S.W.2d 949 (Tex. 1996). In each case, the complaint alleged that side-saddle gas tanks on G M C trucks were susceptible to explosion on impact. B oth nationally and in Texas, a settlement was reached where class members would receive coupons toward the purchase of another G M C truck within 15 months of receiving the coupons. 
funds where unclaimed settlement funds are distributed to persons other than injured class members. ${ }^{11}$

Second, we analyze the pros and cons of nonpecuniary settlements from an economic point of view. We argue that while nonpecuniary settlements can be inefficient, as critics charge, they also can be socially efficient remedies for large-scale misconduct. N onpecuniary settlements can offer benefits to defendants that can be shared with the plaintiff class, making all parties better off. M oreover, nonpecuniary settlements can make efficient use of the inherent organization of the class rather than letting this resource go to waste, as would be the case in an all-cash settlement. The merits of nonpecuniary settlements must, accordingly, be evaluated on a case-by-case basis.

Third, we analyze the considerations that are relevant to this particularized evaluation. We discuss several safeguards that may guard against undesirable nonpecuniary settlements: repeat players, objectors, cash-out provisions, and alternative dispute resolution mechanisms. We propose a cash equivalency test that courts can use in reviewing nonpecuniary settlements: Is the settlement under consideration as good or better, within a range of reasonable error, for members of the class than what realistically could be expected in a cash settlement? We flesh out this test by suggesting detailed standards and factors that courts may consider in particular settlement contexts.

Finally, in an appendix, we investigate the importance of nonpecuniary relief within the overall mix of class action settlements, and we address the hypothesis that the applicable rules on attorneys fees may influence the plaintiffs attorney's choice of forum. We present a sample of 127 class action settlement notices published in the N ew Y ork Times from J anuary 1994 to A ugust 1997, as well as the rules on awarding attorney fees in common fund cases in the federal courts and the fifty state courts.

\section{PRIOR LITERATURE}

There is by now an enormous literature on class action lawsuits, ${ }^{12}$ including a number of valuable papers on class action settlements. M uch of the settle-

11. Traditional injunctive remedies also fall within the general class of nonpecuniary relief, but we exclude these from our analysis because they raise different issues than the ones we address here.

12. On securities class actions, see J anet $C$. A lexander, Rethinking Damages in Securities Class A ctions, 48 StA N. L. REV. 1487 (1996); J ohn W. A very, Securities Litigation Reform: The L ong and Winding Road to the Private Securities L itigation R eform A ct of 1995, 51 B U S. L A W. 335 (1996); J ames Bohn \& Stephen Choi, Fraud in the New-I ssues Market: E mpirical Evidence on Securities Class A Ctions, 144 U. PA . L. R EV. 903 (1996); W illard T. Carleton et al., Securities Class A ction L awsuits: A D escriptive Study, 38 A RIZ. L. R EV. 491 (1996); J ill E. Fisch, Class A ction R eform: L essons from Securities Litigation, 39 A RIZ. L. REV. 533 (1997).

On mass tort class actions, see, for example, J ohn C. Coffee, J r., Class Wars: The Dilemma of the M ass Tort Class A ction, 95 CoLUM. L. REV. 1343 (1995); R oger C. Cramton, Individualized J ustice, M ass T orts, and "Settlement Class A ctions": A n Introduction, 80 COR NELL L. REV. 811 (1995); J onathan R. M acey \& G eoffrey P. M iller, A M arket A pproach to Tort R eform Via Rule 23, 80 COR NELL L. REV. 909 (1995); M ichael A . Perino, Class A ction Chaos? The Theory of the Core and an A nalysis of 


\author{
ment literature is normative, ${ }^{13}$ analytical, ${ }^{14}$ or descriptive, ${ }^{15}$ with a few papers \\ providing empirical data on aspects of the settlement process. ${ }^{16} \mathrm{H}$ owever, there
}

O pt-out R ights in M ass Tort Class A ctions, 46 E M ORY L.J . 85 (1997); William W. Schwarzer, Settlement of M ass T ort Class A ctions: O rder O ut of Chaos, 80 COR NE LL L. REV. 837 (1995).

In general, see Edward H. Cooper, Rule 23, Challenges to the Rulemaking Process, 71 N.Y.U. L. R EV . 13 (1996); Samuel E streicher, Foreword: Federal Class A ctions A fter 30 Y ears, 71 N.Y.U. L. REV. 1 (1996); $M$ arcel K ahan \& Linda Silberman, M atsushita and B eyond: The R ole of State Courts in Cases Involving Exclusive Federal Claims, 1996 SUP. CT. REV. 219 (1997); Larry K ramer, Choice of L aw in Complex Litigation, 71 N.Y.U. L. REV. 547 (1996); Geoffrey P. M iller, Overlapping Class Actions, N.Y .U. L. REV. 514 (1996); Linda S. M ullenix, The Constitutionality of the Proposed Rule 23 Class A Ction A mendments, 39 A RIZ. L. REV. 615 (1997); Thomas D. R owe, J r., B eyond the Class A ction Rule: A n Inventory of Statutory Possibilities to Improve the Federal Class Action, 71 N.Y.U. L. REV. 186 (1996); Thomas E. Willging et al., A n E mpirical A nalysis of Rule 23 to A ddress the Rulemaking Challenges, 71 N.Y.U. L. REV. 74 (1996). For a history of class actions since medieval times, see STEPHEN YEAZELL, FROM MEDIEVAL GROUP LITIGATION TO THE MODERN CLASS A CTION (1987).

13. See, e.g., Susan P. Koniak, Feasting While the Widow Weeps: G eorgine v. A mchem Products, Inc., 80 CORNELL L. REV. 1045 (1995) (lambasting a class settlement for selling out the interests of class members); J udith R esnik, L itigating and Settling Class Actions: The Prerequisites of $E$ ntry and Exit, 30 U. CAL. DAVIS L. REV. 835, 860 (1997) (calling for "thickening information and process"); G eorge R utherglen, B etter $L$ ate Than N ever: N otice and $O$ pt $O$ ut at the Settlement Stage of C lass A Ctions, 71 N.Y.U.L.R EV. 258 (1996) (stressing the importance of the right to opt out).

14. See, e.g., D avid Friedman, M ore J ustice for L ess M oney, 39 J. L. \& E CoN. 211 (1996); B ruce $\mathrm{H}$ ay, O ptimal Contingent Fees in a World of Settlement, 26 J. L E GA L STU D. 259 (1997).

15. For a particularly valuable description of the actual settlement process, see Schwarzer, supra note 12 .

16. A lexander studies the size of settlement in computer and computer-related securities (initial public offering) class actions relative to the strength of the case against the defendant and finds that settlements are fairly consistently $25 \%$ of the potential damages at trial; she hypothesizes that the merits of securities class actions are relatively unimportant to the size of settlement. See J anet C. A Iexander, D o the M erits M atter? A Study of Settlements in Securities Class A ctions, 43 STA N. L. REV. 497 (1991).

Bohn and Choi examine 123 out of 3,519 initial public offerings that generated class action litigation in their sample. See J ames B ohn \& Stephen Choi, Fraud in the N ew-I ssues M arket: E mpirical E vidence on Securities Class Actions, 14 U. PA. L. REV. 903, 928 (1996). These authors find that the vast majority of these lawsuits ( 96 out of 123) settled before trial. See id. at 931 . O nly four suits resulted in a trial, with three verdicts for the defendant and one for the plaintiff. See id. The authors find a statistically significant relation between offering size and incidence of suit; small offerings almost never generate litigation. See id. at 936 . They find that settlement amounts tend to track the size of potential damages awards. See id. at 976 . M ore controversially, they conclude from the data that most securities class actions claiming fraud by the defendant are in fact frivolous, although they do acknowledge at least some evidence for the theory that class action litigation can be related to the merits and can enhance enforcement of the securities laws. See id. at 979-82.

Carleton, W eisbach, and Weiss examine a sample of 348 settled lawsuits, nearly all of them securities class actions. See Carleton, supra note 12, at 491 . They find the median value of settlements is higher, and class periods shorter, for high technology industry cases than for other cases. See id. at 510. They find that only six percent of the settlements are for cases in which the plaintiff alleges that the defendant disseminated misleading information about products under development ("vaporware") cases. See id. They find some evidence of smaller settlements/estimated damages ratios for cases in which settlements were for less than $\$ 2$ million, a result which they interpret as consistent with the presence of nuisance suits settled on the basis of attorney expenses rather than economic damages. See id.

Willging, Hooper and Niemic study class action lawsuits and settlements in four federal district courts. See Federal Jud. Center, Empirical Study of CLASS ACTIONS IN FOUR FEderal District COURTS: FinAl REPORT TO THE AdVISORY COMMITTEE ON CIVIL Rules (1996). They find that across the four districts studied, a substantial majority of certified class actions result in settlements-the percentage of certified class actions ending in settlement range from $62 \%$ to $100 \%$, while settlement rates for cases not certified range from $20 \%$ to $30 \%$. See id. at 60 . The report finds 
is a paucity of scholarship in general on nonpecuniary settlements and none based on empirical work. O ur research has located only two articles devoted to the topic. A student note in the $\mathrm{H}$ arvard $\mathrm{L}$ aw Review identifies and describes a variety of coupon settlements and discusses the problem that the uncertain valuation of such settlements creates for judges who must review a settlement's fairness, adequacy, and reasonableness. ${ }^{17}$ The note does not address the economics of coupon settlements, generalize from coupon settlements to nonpecuniary settlements, provide a standard (plus relevant factors) that a court might use in reviewing a coupon settlement, or place the analysis within an empirical context. A $n$ article in the Journal of $L$ aw and $E$ conomics formally models the difference between time-limited and dollar-limited coupon settlements, but does not deal with other types of nonpecuniary settlements and does not address the public policy arguments for and against these devices. ${ }^{18}$ A ccordingly, this paper presents the first comprehensive analysis of nonpecuniary class action settlements in the literature.

III

\section{Ty PES OF N ONPECUNIARY SETTLEMENTS}

A nonpecuniary settlement is a settlement of a class action lawsuit in which the defendant, in exchange for a release of legal claims, provides consideration other than an immediate cash payment to defined members of the class. We exclude from consideration traditional injunctive remedies, which, although nonpecuniary in nature, present considerations different from the ones addressed here.

For descriptive purposes, we divide nonpecuniary settlements into five categories: coupon, monitoring, securities, reverter, and fluid recovery settlements. M ost of the settlements are reached as a result of Federal $\mathrm{R}$ ule of Civil Procedure 23(b)(3) class actions or a state analog, ${ }^{19}$ although some arise under

no particular relationship between timing of certification and settlement, contrary to what might have been expected given the importance of certification in the process of class litigation. See id. at 61-62.

A study by the National E conomic R esearch A ssociation examines characteristics of filing and settlements in a sample of securities class actions. See DENISE N. MARTIN, ET AL., RECENT TRENDSIV: What Explains Filings and Settlements in Shareholder Class Actions (N.E.R.A., Nov. 1996).

17. See N ote, In-K ind Class A ction Settlements, 109 H A R V. L. REV. 810 (1996) (discussing the use of and problems with in-kind class action settlements); see also Roberta Romano, The Shareholder Suit: Litigation Without Foundation, 7 J . L. E CON. \& ORG. 55, 61 (1991) (observing that nonpecuniary settlements present severe valuation problems).

18. See Severin Borenstein, Settling for Coupons: D iscount Contracts as Compensation and Punishment in A ntitrust L awsuits, 39 J . L . \& E con. 379 (1996).

19. Federal Rule of Civil Procedure 23(b)(3) states that a class action may be maintained if the requirements of R ule 23(a) are satisfied and if, in addition, "the court finds that the questions of law or fact common to the members of the class predominate over any questions affecting only individual members, and that a class action is superior to other available methods for the fair and efficient adjudication of the controversy." The matters pertinent to the findings include the following: "(A) the interest of members of the class in individually controlling the prosecution or defense of separate actions; (B) the extent and nature of any litigation concerning the controversy already commenced by or against members of the class; $(\mathrm{C})$ the desirability or undesirability of concentrating the litigation of the 
R ule 23(b)(1). ${ }^{20}$ G enerally, as part of the settlement, the defendant agrees to pay all costs of notice and administration as well as the plaintiffs' attorneys' fees. The defendant usually includes a cash component with the nonpecuniary settlement to finance these costs and fees. ${ }^{21}$ Typically, the defendant denies all wrongdoing, and the class releases the defendant from any and all liability in connection with the allegations in the complaint.

\section{A . Coupon Settlements}

A coupon settlement is a settlement where the defendant creates a right for class members to obtain a discount on future purchases of the defendant's products or services. The right to receive a discount is the consideration class members receive instead of an immediate cash payment. The defendant receives a release from legal claims and the benefit of the consumers' increased incentives to purchase one of its products or services.

A classic example of a coupon settlement is the Computer M onitor Cases, ${ }^{22}$ a nationwide class action on behalf of all persons in the $U$ nited States who purchased personal computers from a wide variety of manufacturers and retailers. The complaint alleged that the defendants failed to disclose the actual viewable image size in monitor screens at the time of sale. Under the terms of the settlement, if class members submit a properly completed form (attached as A ppendix $B$ ) to the settlement administrator, they have the right to receive a $\$ 13.00$ rebate on qualifying purchases of monitors, computer systems, or other computer hardware having a unit purchase price of $\$ 250$ or more. Class members who do not take advantage of the $\$ 13.00$ rebate offer have the right to request a $\$ 6.00$ cash payment up to a maximum of five rebates. However, requests for the $\$ 6.00$ in cash may submitted only after September 7, 2000 and for six months thereafter. Settlement class members who verify that they pur-

claims in the particular forum; and (D) the difficulties likely to be encountered in the management of a class action." Id.

Federal Rule of Civil Procedure 23(a) provides that "[0]ne or more members of a class may sue or be sued as representative parties on behalf of all only if (1) the class is so numerous that joinder of all members is impracticable, (2) there are questions of law or fact common to the class, (3) the claims or defenses of the representative parties are typical of the claims or defenses of the class, and (4) the representative parties will fairly and adequately protect the interests of the class."

20. R ule 23(b)(1) states that a class action may be maintained when the prerequisites of $23(\mathrm{a})$ are satisfied, and where, in addition, "the prosecution of separate actions by or against individual members of the class would create a risk of (A) inconsistent or varying adjudications with respect to individual members of the class which would establish incompatible standards of conduct for the party opposing the class; or (B) adjudications with respect to individual members of the class which would as a practical matter be dispositive of the interests of the other members not parties to the adjudication or substantially impair or impede their ability to protect their interests." FED. R. CIV. P. 23(b)(1).

21. Though in certain circumstances, such as the defendant's financial distress, the court might award the attorneys a fee that comes directly from the settlement in kind, rather than a cash fee. See, e.g., Seidman v. A merican M obile Systems, 965 F. Supp. 612 (E.D. Pa. 1997) (granting class counsel a fee of $25 \%$ of the recovery in the form of cash, stocks, and warrants, proportionally derived from the settlement).

22. J udicial Council Coordination Proceeding N o. 3158, Cal. Super. Ct. (County of San Francisco), Summary N otice of Pendency and Settlement of Class A ction, M ar. 11, 1997, published in N.Y. TIMES, A pr. 1997. 
chased primarily for personal, family, or household purposes may transfer their rebate form one time to any person, but the recipient may claim only the $\$ 13.00$ rebate on new purchases, not the $\$ 6.00$ cash payment. As part of the settlement, the settling companies agree to pay all costs of notice and administration of the settlement, as well as attorneys' fees of class counsel of $\$ 5.8$ million. The defendants agree "to maintain and provide certain procedures and disclosures nationwide regarding the advertisement of the actual viewable screen area for personal computer monitors" for a period of three years. ${ }^{23}$

The Computer Monitor Cases settlement includes an actual coupon. In other settlements, no coupon is distributed, but class members nevertheless are entitled to some sort of favorable treatment on future purchases. These settlements are analogous to settlements involving actual coupons because the class member obtains relief only by continuing to do business with the defendant. A $n$ example of this type of settlement is seen in Michels v. Phoenix Home Life Mutual Insurance Co., ${ }^{24}$ where the company allegedly committed false or deceptive behavior in the sale of whole and universal life insurance policies. The class is entitled to receive relief from the defendant not through purchasing new products or services, but by maintaining or reactivating an insurance policy. The consideration given to the class member is not a right to receive a discount in the future, but a right to receive a more valuable insurance policy than she currently holds. U nder the terms of the settlement, class members with policies in force are entitled to a variety of benefits provided they keep their policies in effect. These benefits include, depending on the nature of the policy, a "dividend enhancement" (an increase in the dividends to which the policyholder is entitled from the company), an "optional premium loan" (a loan against the accrued value of the policy in force), an "enhanced value annuity" (an annuity contract with increased payouts), or a "mutual fund enhancement" (an investment in a mutual fund with increased benefits). Class members with lapsed or surrendered policies are eligible to apply for an enhanced value policy and to obtain either an enhanced value annuity or a mutual fund enhancement investment.

\section{B. Monitoring Settlements}

M onitoring settlements are settlements where the defendant endows a fund which is used to identify and compensate for future harm allegedly arising from the defendant's product or conduct. Most such settlements take the form of medical monitoring in cases of exposure to toxic substances, as in the recent A mchem case. ${ }^{25}$ However, monitoring settlements are possible in other contexts where a product may be defective and monitoring can identify whether harm to the product has occurred from that defect. In all monitoring settle-

23. Id.

24. Index No. 5318-95, N.Y. Sup. Ct. (County of A Ibany), Notice of Settlement, May 1997, published in N.Y. TIMES, M ay 1997.

25. A mchem Products, Inc. v. W indsor, 117 S. Ct. 2231 (1997) (rejecting settlement). 
ments, the consideration received by the class is ongoing testing for the harm and, if the harm appears, treatment of the injury or damage. The defendant receives a release from legal claims by members of the class and, if the fund is limited, a cap on the money it must pay the class. ${ }^{26}$

A rather straightforward example of a medical monitoring settlement is Woodward v. Nor-A m Chemical C $0 .{ }^{27}$ Persons exposed to toxic agricultural pesticides sued the manufacturer alleging that exposure to the substance can cause bladder cancer and hemmorrhagic cystitis. The parties reached a settlement that included a limited fund for ongoing medical monitoring, reimbursement for the cost of treatment of certain medical conditions, and payment of compensation for injury or death. In re Packard Bell Consumer Class A ction Litigation ${ }^{28}$ is a monitoring settlement outside the medical context, involving claims of defects in certain Packard B ell products. The manufacturer created a six-month extended service contract for class members who submit a registration card to the claims administrator. The extended service contract covers, on a "carry-in" basis to authorized Packard B ell Service Centers, materials and labor required for replacement or repair of defective hardware. ${ }^{29}$ If no harm occurs, Packard Bell will pay a class member nothing, but if the defect causes damage, Packard Bell is obligated to repair it. Specific testing is not required because consumers know when their computers break.

\section{Securities Settlements: Stocks, Puts, and W arrants $^{30}$}

A securities settlement is a settlement where the defendant distributes stocks, puts, or warrants instead of cash to members of a class as consideration for a release of claims for alleged wrongdoing. In a sense, the defendant is raising new capital (in the form of a release of claims) from a group of purchasers highly disposed to buy. ${ }^{31}$ The securities settlement resembles a traditional corporate rights offering or prescription offering in that a limited, predefined group is offered the opportunity to purchase the company's securities. The class relinquishes a valuable economic claim in return for equity (stock) or an entitlement to equity (options and warrants) in the company.

26. If a company faces individual claims, it may have to pay high damages to each claimant whether or not the person or product develops the harm. If harm later develops, and the company has been forced into bankruptcy by the earlier occurring lawsuits, people may get no compensation. In a monitoring settlement, if the company has a plan for allocating resources among class members and can spread its payments out over time, it may be able to finance its obligations from future earnings.

27. Civ. N o. 94-0780-CB-C, 1996 U .S. D ist. LEXIS 7372 (S.D. A la. 1996).

28. Case N o. BC 125671, Cal. Super. Ct. (County of L os A ngeles), N otice of Settlement, J une 29, 1995, published in N.Y. TIMES, J uly 1995.

29. This settlement also has a coupon feature: To activate the extended service contract, the class member must pay a one-time $\$ 25$ fee at the time of equipment failure.

30. For purposes of this article, we will assume the securities settlement involves an equity issue, though there is no reason a securities settlement could not involve debt issuance.

31. The alternative to buying the securities is for a class member to opt out of the settlement and incur the costs of individually pursuing a lawsuit against the company, or simply to not participate in the recovery at all. 
A $n$ example of a stock settlement is I $\mathrm{n}$ re TSO Financial Litigation. ${ }^{32}$ The settlement provides a fund of the defendant's common stock valued at \$2.1 million plus a cash component of $\$ 750,000$. Class members receive stock in the company in proportion to their losses. The settlement agreement contains a "share value guarantee" with respect to the stock fund, under which, in the event the defendant's stock does not trade at or above $\$ 12$ per share during a consecutive ten-day trading period over the four years ensuing from the date of settlement, the defendant will pay the difference between the trading value and $\$ 12$ either in cash or additional stock to class members who still hold their securities. A t settlement time, the company's stock was trading at \$7.87 per share.

A put option settlement is a variant on the common stock settlement. The put provides assurances that the stock of a company will not go down below the put exercise price. However, the put has value only if a class member still holds stock in the company or the put is transferable. In Derdiarian v. Futterman Corp., ${ }^{33}$ the defendant agreed to issue one put option for each share of its stock purchased during the period of the alleged wrongdoing. The options entitled the holder to put one share of stock to the corporation for $\$ 6$ during the last ten days of either of the two years after its issuance. The defendant retained the right to call the options at any time prior to exercise for $\$ 1.25$ each. A the time of settlement, the company's stock was trading at $\$ 5.62$ per share. The option holders had the right to sell their options to the company within sixty days of issuance for seventy cents each. The D erdiarian settlement allowed the holders of the put options to profit if the company's stock went down in the market, since they had the right to receive $\$ 6$ a share from the company on the exercise date. The company, however, could limit its liability by calling the options if it believed it would have to pay more than $\$ 1.25$ per option when the option holders exercised their put. If the company's stock were to go up in the market, the option holders would not profit from the options, but they would gain the benefit of the price rise in their underlying shares.

Warrant settlements introduce a slight twist into the basic securities settlement. The holder of a warrant has the right to purchase stock at a stated price in the future. Because the strike price of the warrant is always set at a level above the current market value of a company's stock, it is not in a class member's interest to exercise the warrant until some future date at which the value of the company's stock exceeds the strike price. ${ }^{34}$ A $n$ example of a warrant settlement is Seidman v. A merican M obile Systems, ${ }^{35}$ a securities class action by purchasers of a firm's common stock who claimed that the defendants' misrep-

32. Civ. No. 87-7903, 1989 U.S. D ist. LEXIS 7434 (E.D. Pa. 1989).

33. 254 F. Supp. 617 (S.D.N.Y. 1966).

34. Suppose, for example, that the company's stock is trading at $\$ 5$, and the strike price of the warrant is $\$ 8$. If the stock goes up above $\$ 8$, say to $\$ 10$, the warrant holder can make a profit of $\$ 2$ by exercise. On the other hand, if the stock goes up only to $\$ 6$ during the period of the warrant, it will never be in the interest of the warrant holder to exercise the right, since he or she would have to pay $\$ 8$ for stock with a market value of $\$ 6$.

35. 965 F. Supp. 612 (E.D. Pa. 1997). 
resentations had caused them to pay too high a price. The settlement with the defendant issuer provided for payment of $\$ 200,000$ in cash, $\$ 225,000$ in either cash or common stock, and eighteen-month warrants to purchase shares of common stock. This settlement reduced the cash payout required by the defendant while giving aggrieved class members the right to share in any increase in value of the company, both by virtue of holding stock and by exercising warrants if and when the company's stock rose in value above the strike price of the warrants.

\section{R everter Fund Settlements}

R everter funds are, in a sense, not properly classifiable as nonpecuniary settlements since they involve a cash payment by the defendant. However, reverter funds do not involve an immediate cash payment because the defendant pays an escrow agent instead of directly paying class members. Class members must apply to the escrow agent or claims administrator to receive their money. A the end of the payment period, if all class members have not submitted claims for their share of the fund, the excess in the escrow account reverts to the defendant.

The escrow account provides class members with security that they will receive their money so long as they qualify for an award and they follow the necessary application procedures. The consideration received by the class is the right to receive the agreed-on payments, plus the security the escrow account provides. In exchange for establishing the escrow account, the defendant receives an immediate release of liability at the time of settlement. B oeing v. Van G emert $^{36}$ is a well-known reverter fund case. ${ }^{37}$ The district court established a fund of $\$ 3,289,359$, plus prejudgment interest, and ordered the defendant to pay the fund into an escrow account at a bank. Class members were known with certainty, and each member had a present vested interest in the escrow fund that could easily be valued. If class members failed to claim the full amount of the fund, it appeared that the remaining funds would return to the defendant. ${ }^{38}$

\section{E. Fluid R ecovery Settlements}

A fluid recovery, or cy pres, settlement is one in which some or all of the settlement funds are distributed to persons or entities who have not established their right to relief and/or have not suffered actual damage. ${ }^{39}$ R ecipients of relief may include nonclass members such as charities or funds to promote schol-

36. 444 U .S. 472 (1980).

37. U nusually, the case went to trial on the merits rather than settling. H owever, the case is also illustrative in the settlement context.

38. The Supreme Court concluded that the defendant had at least a "colorable" right to the unclaimed funds. See B oeing, 444 U .S. at 477.

39. On fluid recovery funds, see generally K enneth $D$ am, Class A ctions: E fficiency, Compensation, Deterrence and Conflict of Interest, 4 J . LE GA L STU D. 47 (1975); M ichael M alina, Fluid Class Recovery as a Consumer Remedy in A ntitrust Cases, 47 N.Y .U. L. REV . 477 (1972); Comment, Damage Distribution in Class A ctions: The Cy Pres Remedy, 39 U . CHI. L. R E V. 448 (1972). 
arship or public safety. Typically, in fluid recovery cases, the class is large, each member has a small claim, and a large fraction of the class either cannot be identified or is unlikely to file a claim even if notified of the lawsuit. ${ }^{40}$

In Gordon G redell v. Wyeth Laboratories, Inc., ${ }^{41}$ the class consisted of all consumers within the $U$ nited States who purchased one of five Phenergan expectorant drug products between 1973 and 1984. W yeth L aboratories allegedly omitted a disclosure statement that the drug products had not been proven to provide relief of coughs due to colds. In the notice to the class, $G$ redell was set for trial and the plaintiffs' attorneys requested that the court consider distributing any recovery in a manner other than directly to the class. ${ }^{42} \mathrm{G}$ redell presents an obvious case for fluid class recovery, since the costs of identifying people who purchased cough medicine over a ten-year period would be prohibitive.

IV

The ECONOMICS OF NONPECUNIARY SeTtLements

\section{A. The Case A gainst N onpecuniary Settlements}

A common feature of all nonpecuniary settlements is that valuation is inevitably problematic. The value of a contemporaneous cash settlement paid to defined beneficiaries is a straightforward determination: O ne simply calculates the payments owed and adds them up. However, nonpecuniary settlements have features that make them difficult to appraise.

The case against nonpecuniary settlements is based on the proposition that plaintiffs' attorneys and defense counsel can manipulate a nonpecuniary settlement in order to give it an unrealistically high valuation. Such behavior enhances the likelihood that the settlement will be approved in court and may increase the attorneys' fees awarded to plaintiffs' counsel, but the actual benefits to the class may suffer as a result.

In this subsection, we discuss these valuation problems, highlight the agency problems inherent in the role of "entrepreneurial" attorneys in class action litigation, and, finally, observe how self-interested attorneys can manipulate the valuation of nonpecuniary settlements to benefit themselves at the expense of the class.

40. A n example is all milk drinkers in the state of California who have been injured by unlawfully fixed milk prices. See Bruno v. Superior Court, 179 Cal. R ptr. 342 (Cal. Ct. A pp. 1981).

41. Case N o. 87 CH 8445, III. Cir. Ct., Ch. D iv. (Cook County), N otice of Settlement, J uly 7, 1994, published in N.Y. TIMES, Nov. 1994.

42. For an example of a fluid recovery in the settlement context, see In re Insurance A ntitrust $L$ itigation, M D L N o. 767, No. C 88-1688 (CA L), N.D. Cal., N otice of Pendency of Class A ction and Proposed Settlement and H earing, J an. 17, 1996, published in N.Y. TIMES, J an. 1995 (proposed settlement of $\$ 21$ million to go toward developing the Public Entity R isk Institute, which would provide training, education, and technical services to public entities and other policyholders that share many of the same insurance needs as public entities). 
1. Valuation Problems in N onpecuniary Settlements. In coupon settlements, class members receive the right to a discount on the purchase of a product or service. If all class members intended to purchase the given product or service already, and proceeded to do so using their coupons, valuation would be easy. In the real world, however, many consumers do not want to purchase the item in question. For them, the right to receive a discount will be worthless, unless they can transfer the coupon for value to someone who does want the item. E ven if transfer of coupons is permitted, the process is likely to be costly and inefficient, and the original holders of the coupons will surely receive less - often drastically less than the amount of the discount upon sale. The amount they will receive if they sell cannot easily be determined at the time of settlement.

M oreover, even if a class member exercises the coupon and purchases the item or service in question, this fact in itself does not indicate that the consumer has received the full value of the discount. A ssume that the consumer does not particularly want to buy the item in question-say, a bottle of shampoo. A lthough the market price of the shampoo is five dollars, the consumer would not be willing to pay more than three dollars for a bottle. Now the consumer receives a coupon as part of a class action settlement entitling her to purchase a bottle of shampoo for two dollars, a discount of three dollars. The consumer will purchase the shampoo and use the coupon. However, she has not received a benefit of three dollars. The benefit to her is only one dollar: the difference between the amount she was willing to pay for the shampoo (three dollars) and the amount she had to pay (two dollars). Thus, even with respect to persons who exercise their coupons, one cannot assume that the value of the coupon is equal to the full value of the discount over market price.

In the case of monitoring settlements, the value of the relief depends on how many class members avail themselves of the monitoring process and how many eventually require the treatment (or service) for which the defendant will pay. It also depends on how much the treatment or service costs at the time of need. Monitoring settlements sometimes involve a limited fund, so the amount the defendant must pay the class is capped. If there is a cap on the settlement, there will be a ceiling that constrains the value of the settlement on the high end. However, the defendant ultimately might pay out only a fraction of the fund, so it is impossible ex ante to tell what the total cash value of the settlement will be.

Securities settlement valuation problems primarily result from not knowing ex ante how much a particular security will be worth to the class in the future. With stock settlements, a share value guarantee may place a floor under the stock's value for a certain length of time, but otherwise it is unknown what market valuation of the stock will be. Puts also create a floor for class members, but under stock they separately own. The value of a put to a class member and cost to the defendant depends on where the stock is trading during the put time period, and could be worthless if the stock trades above the put value, or worth at most a low amount if the defendant has a right to call the put at any 
time for that low amount, and does so. The value of warrants depends on whether the company's stock ever rises above the value during the warrant time period, so that it is worthwhile for class members to exercise the warrant. With stocks, puts, and warrants, the impossibility of ex ante market valuation means that it is difficult to tell what the securities ultimately will be worth in cash.

The potential total value of a reverter fund settlement to the class is known, and protected by being placed in an escrow account, but the actual value to the class and cost to the defendant depends on how many class members apply to receive funds from the account. Generally, an escrow account is used when there is a long payout period and the class is not directly given its recovery, but must apply for it (even if the identity of class members is known to the defendant). W ith a reverter fund, it is unclear how much money will be paid out. Hence, under a reverter fund, the ultimate value of the fund to the class is unknown until the time period for claiming funds has expired and the remainder in the escrow account has been returned to the defendant.

The valuation of a fluid recovery fund can be exceedingly complicated because some or all payments in a fluid recovery go to persons other than class members who have suffered harm. If others get part of the fund, the value of the settlement may not be the value to the class members only, since the defendant is paying out additional sums. Should sums received by others receive full credit in the valuation process? W hat about moneys that are paid for ostensibly eleemosynary purposes, such as charities or public education campaigns? Perhaps the value of the settlement should be considered to be the full amount paid out by the defendant, for whatever purpose, but this valuation severs the link between value and recovery to the class members.

In short, each of the five categories of nonpecuniary relief presents significant, albeit distinctive, issues of valuation.

2. The Role of the Entrepreneurial Attorney. Litigation leading to nonpecuniary settlements, like all class action litigation, is subject to the general problem of the plaintiffs' attorney who functions as an "entrepreneur" free of substantial monitoring by her ostensible "clients." ${ }^{43}$ When class counsel retains almost total control over a class's case, including making the decision about whether to accept a settlement, there is legitimate concern about a potential conflict of interest between class counsel and the class. The attorneys

43. This is an important theme of J ohn Coffee's work. See Coffee, supra note 12; J ohn C. Coffee, $J$ r., The Regulation of E ntrepreneurial L itigation: B alancing Fairness and Efficiency in the $L$ arge Class A ction, 54 U. CHI. L. R EV. 877 (1987); J ohn C. Coffee, J r., Understanding the Plaintiff's A ttorney: The Implications of E conomic Theory for Private E nforcement of $L$ aw Through Class and Derivative ACtions, 86 ColuM. L. REV. 669 (1986); J ohn C. Coffee, J r., The Unfaithful Champion: The Plaintiff as M onitor in Shareholder L itigation, 48 LA W \& CONTEM P. PR OBS. 5 (Summer 1985); J ohn C. Coffee, J r., Rescuing the Private $A$ ttorney $G$ eneral: Why the $M$ odel of the $L$ awyer as B ounty $H$ unter is N ot Working, 42 M D. L. REV. 215 (1983). Similar arguments are found in J onathan R. M acey \& G eoffrey P. M iller, The Plaintiffs' A ttorney's Role in Class Action and D erivative L itigation: E conomic A nalysis and Recommendations for Reform, 58 U . CHI. L. R EV. 1 (1991). 
find the cases, locate the named plaintiffs, and control all aspects of the litigation, using the representative plaintiff as little more than the key to the courthouse door. U nder these conditions, there is a danger that class counsel may accept a settlement that is less favorable to the class than what counsel might obtain by further prosecution of the case. The defendant can make it advantageous for counsel to accept such an offer by agreeing to pay generous attorneys' fees. From the defendant's point of view, it makes little difference whether money is paid to class counsel or to the class. ${ }^{44}$ The defendant wants to minimize the sum of attorneys fees' and substantive class relief. A purely selfinterested plaintiffs' attorney, on the other hand, wants to obtain as great a profit as possible. $^{45}$

Consider the following two settlements, either of which defendant would sign:

\begin{tabular}{|lcc|}
\hline R ecipient(s) & Settlement 1 & Settlement 2 \\
\hline A ttorney & $\$ 100$ & $\$ 200$ \\
Class & $\$ 900$ & $\$ 700$ \\
Total & $\$ 1,000$ & $\$ 900$ \\
\hline
\end{tabular}

Settlement 1 is preferable for the class, because the class members receive $\$ 200$ more than in settlement 2. However, settlement 2 is preferable both for class counsel, who receives $\$ 200$ in fees rather than $\$ 100$ as in settlement 1 , and for the defendant, whose total costs are only $\$ 900$ as compared with $\$ 1,000$. If class counsel primarily is interested in the fee he earns today, class counsel likely will arrange settlement 2 with the defendant, as opposed to continuing litigation to reach settlement 1.

The concern about the potential conflict of interest between the class and class counsel becomes more acute when parallel class actions are filed in multiple jurisdictions. A ny of these "overlapping class actions" ${ }^{46}$ may result in a settlement that cuts off the other class claims. ${ }^{47}$ The defendant, therefore, can play plaintiffs' attorneys in the different jurisdictions against one another in a "reverse auction," ${ }^{48}$ looking to negotiate a settlement with the attorneys who will accept the lowest amount of damages and attorneys' fees combined.

44. However, the defendant may want to minimize the award to class counsel in order to deter future class litigation.

45. Obviously, the assumption that plaintiffs' attorneys are purely self-interested in the short term does not hold true in practice. A plaintiff's attorney may sacrifice some of her fee in order to gain more in damages for the class, or may accept a lower fee today in order to attract more business so that she will maximize her income over time.

46. See G eoffrey P. M iller, O verlapping Class A ctions, 71 N.Y .U . L. R E V. 514 (1996).

47. This problem has increased greatly with the Supreme Court's holding in M atsushita Electrical Industrial Co. v. Epstein, 116 S. Ct. 873 (1996), that state courts have jurisdiction to enter binding judgments over claims in class action lawsuits that they would not have had authority to hear originally.

48. The leading treatment of this problem is in Coffee, supra note 12. 
3. Special Problems of Nonpecuniary Relief. When nonpecuniary settlements are being negotiated instead of cash awards, there is an added level of complexity because the defendant and class counsel have an opportunity to manipulate the valuation of the settlement in order to serve their individual purposes. The problem of sacrificing class recovery for the attorneys' fee becomes exacerbated. B ecause the fee is typically in cash, the ratio of the fee to the class recovery can be manipulated by exaggerating the value of the nonpecuniary class settlement. Thus the fee may seem a smaller percentage of the class recovery than it is in fact.

Consider the following settlement, where the plaintiffs attorneys obtain the maximum value possible from the defendant, but use uncertainties of valuation to disguise the percentage of the settlement represented by their fee:

\begin{tabular}{|llll|}
\hline R ecipient(s) & \multicolumn{1}{c}{$\begin{array}{c}\text { A ttorneys' } \\
\text { A ppraisal }\end{array}$} & $\begin{array}{c}\text { A ctual V alue } \\
\text { (not observed) }\end{array}$ & $\begin{array}{c}\text { B est A vailable } \\
\text { Settlement for Class }\end{array}$ \\
\hline A ttorney & $\$ 500$ cash $(33.3 \%)$ & $\$ 500$ cash $(41.6 \%)$ & $\$ 400$ cash $(33.3 \%)$ \\
Class & $\$ 1,000$ nonpec. & $\$ 700$ nonpec. & $\$ 800$ cash \\
Total & $\$ 1,500$ & $\$ 1,200$ & $\$ 1,200$ \\
\hline
\end{tabular}

U nder the settlement as appraised by the attorneys, the attorneys receive one third of the fund. H owever, under the actual value of the settlement, the attorneys receive $41.6 \%$ of the fund. Thus, the attorneys have manipulated the valuation of the settlement in order to make the fee seem smaller, as a percentage of the class relief, than it actually is. A ssuming the defendant will not pay more than $\$ 1,200$ in total, and the rule on fees in the applicable jurisdiction provides that attorney's receive one-third of the total recovery, with the court's rule would benefit the class which received $\$ 800$ cash and the attorneys $\$ 400$. The class would be better off because it would receive a total compensation of $\$ 800$ as opposed to $\$ 700$.

Nonpecuniary settlements also can be used to disguise the fact that the plaintiffs' attorneys have obtained a less-than-optimal settlement from the defendant in exchange for a high fee. Consider the following example:

\begin{tabular}{|lcll|}
\hline R ecipient(s) & $\begin{array}{c}\text { A ttorneys' } \\
\text { A ppraisal }\end{array}$ & $\begin{array}{c}\text { A ctual V alue } \\
\text { (not observed) }\end{array}$ & $\begin{array}{c}\text { B est A vailable } \\
\text { Settlement for } \\
\text { Class }\end{array}$ \\
\hline A ttorney & $\$ 500$ cash $(33.3 \%)$ & $\$ 500$ cash $(50 \%)$ & $\$ 400$ cash $(33.3 \%)$ \\
Class & $\$ 1,000$ nonpec. & $\$ 500$ nonpec. & $\$ 800$ cash \\
Total & $\$ 1,500$ & $\$ 1,000$ & $\$ 1,200$ \\
\hline
\end{tabular}


The difference between this case and the previous one is that the unobserved actual value $(\$ 1,000)$ is less than what could be obtained from the defendant if the case were litigated in the best interests of the class $(\$ 1,200)$. $\mathrm{H}$ ere, the defendant has agreed to give the plaintiffs' attorneys a higher fee ( $\$ 500$ instead of $\$ 400$ ) in return for a reduction in the total amount that the defendant will have to pay to settle the case (from $\$ 1,200$ to $\$ 1,000$ ). The class loses in two ways: The attorneys receive a larger share of the total recovery than what they are entitled to under the rules of the jurisdiction, and the class loses an additional amount ( $\$ 200)$ to the defendant because class counsel has traded off a lower total recovery against a higher fee. ${ }^{49}$

Plaintiffs' attorneys and defense counsel have yet another reason to present an exaggerated valuation of the recovery to the court: The larger the apparent recovery, the more likely it is that the court will approve the settlement. If the defendant offers a low amount in cash, the court might reject the settlement as inadequate. The plaintiffs' attorneys have an incentive to support the defendant's valuation because they want the settlement approved in order to receive their fee.

A s a final complication, the plaintiffs' attorneys may use the valuation potential of the settlement to shop for high fees among the different jurisdictions that can hear the case. If the attorneys can find a court that awards a fee based on the percentage of the recovery ${ }^{50}$ and that will accept a high valuation of the settlement, it is possible this court will award an attorneys' fee that is higher than any other percentage jurisdiction or lodestar jurisdiction. ${ }^{51}$ A gain, this fee will come at expense of the class's optimal recovery because the attorneys' fee should be predicated on the actual value of the fund the class receives.

\section{B. The Case for Nonpecuniary Settlements}

In this subsection, we address the efficiencies and deterrence effects that can make nonpecuniary settlements desirable over cash settlements, even if there is potential for conflict between the entrepreneurial attorney and the class.

The efficiencies of nonpecuniary settlements arise because of benefits such settlements can offer either to the plaintiff, the defendant, or both-benefits that can be shared between the parties, making everyone better off. For exam-

49. See William J . Lynk, The Courts and the Plaintiff's Bar: A warding the A ttorney's Fee in Class A ction L itigation, 23 J. LEGA L STUD. 185, 191-94 (1994) (trade-off between recovery and fee); G eoffrey P. M iller, Some A gency Problems in Settlement, 16 J. L E G A L STU D. 189 (1987) (same).

50. There are two general methodologies for calculating attorneys' fees in class actions. U nder the percentage method, the fee is determined as a fraction of the class recovery. Under the lodestar method, the fee is based on the number of hours reasonably expended by class counsel times the reasonable hourly rate, and adjusted for various factors.

51. Generally, the attorneys can expect to receive an award of between $25-35 \%$, though a court may award any percentage of the recovery it sees fit in the particular case. See FEDERAL JUD. CENTER, supra note 16 , at 73 . 
ple, the settlement process creates a list of names and addresses of people allegedly harmed by the defendant's behavior. These people will share common interests and tastes: not only their interest in being reimbursed for the alleged injuries they have suffered, but also their interest in the product or services that caused them to suffer injury in the first place. A nonpecuniary settlement targeted at this specific group, with its particular concerns, can be an efficient way for the defendant to make the class whole while at the same time conserving on its own expenditures, for example in either for marketing and distribution or for capital formation. In other cases, the fact that a class action brings together large numbers of people with similar interests may make nonpecuniary settlements preferable from the standpoint of the class members. For example, nonpecuniary settlements may allow the class to manage more efficiently the risk of injury or risks that members of the class will not be paid because of the defendant's intervening insolvency. The savings to the defendant and/or to the class can be shared among the settling parties for their mutual benefit, so that all parties end up better off with a nonpecuniary settlement than they would be with a cash settlement.

O ne might object that, while the parties may be better off, society will be harmed because the reduced amounts defendants pay in nonpecuniary settlements will translate into a lower level of deterrence of corporate misconduct. For example, if a defendant knows it will have to pay $\$ 1000$ in a nonpecuniary settlement instead of $\$ 5000$ in cash damages, the defendant will not spend more than $\$ 1000$ to prevent a defective product from reaching the market. This may seem like a socially inefficient outcome. However, if the goal of social policy is to make the defendant internalize the costs of harm, a properly structured nonpecuniary settlement will serve deterrent purposes just as well as an all-cash settlement. With a nonpecuniary settlement, the defendant's cost of liability may be reduced, but the defendant will incur the full economic cost of its harm because the defendant makes the class whole. A ccordingly, if properly structured, nonpecuniary settlements can fully compensate plaintiffs and increase overall social wealth without sacrificing the goal of deterring wrongful conduct.

1. Coupon Settlements. Coupon settlements may be desirable over cash settlements if the defendant can save the difference between the wholesale and the retail cost of marketing its goods or services and pass at least part of that difference on to class members. The coupon settlement process may be analogized to a simple dispute between a consumer and a merchant. Suppose, for example, that a dry cleaner ruins a valuable suit. The dry cleaner might be unwilling to settle the case for the full value of the suit, in which case the parties would have to go to small claims court to resolve the dispute (or the customer would have to accept the loss without compensation). But the drycleaner might be willing to give the customer the value of the suit in store credit. In so doing, the drycleaner incurs only the drycleaner's wholesale cost of cleaning new garments, while the customer gets the benefit of drycleaning for which the customer would have to pay retail in any event. If, despite the 
mistake with the suit, the drycleaner is a competent provider of cleaning services, and if the customer needs more garments drycleaned, the deal will be advantageous to both parties: The drycleaner retains the customer's business, which will be valuable in the future, while minimizing its costs by providing store credit rather than cash and the customer gets a service at a discount.

The same principles apply in class action litigation. Say a class of 1,000 people have been harmed by the defendant in the amount of $\$ 5$ each, because they each purchased one bottle of shampoo from a defective production run. The full pecuniary damages needed to make the consumers whole is therefore $\$ 5,000$. A ssume that the shampoo is an excellent quality product that the consumers would be happy to use again, although they would slightly prefer to switch to a competing brand given their recent bad experience with the defendant's product. The shampoo costs the manufacturer $\$ 2.50$ per bottle to produce. A ssume further that there are no litigation costs and no attorneys' fees. The settlement options are as follows:

\begin{tabular}{|cc|}
\hline Settlement 1 & Settlement 2 \\
\hline \$5 cash & $\begin{array}{l}\text { Coupon for two new } \\
\text { bottles at \$2/bottle }\end{array}$ \\
\hline
\end{tabular}

The defendant is clearly better off with settlement two. A cash settlement costs the defendant $\$ 5,000$ and will not bring back any customers. A nonpecuniary settlement costs the defendant at most $\$ 1,000$ (assuming all coupons are redeemed, the defendant will sell an additional 2,000 bottles of shampoo for $\$ 2$ each, for a loss per bottle of $\$ .50$ and a total loss of $\$ 1,000$ ). The defendant saves $\$ 4,000$ on the settlement.

What about the members of the class? This coupon settlement is beneficial to them also, as compared with a cash settlement. They need to buy shampoo in any event, and they are happy to purchase the defendant's shampoo at $\$ 5$ per bottle, although they would slightly prefer to buy a competitor's product at the prevailing market prices. The cash settlement gives consumers $\$ 5$ each. The coupon settlement, on the other hand, gives consumers a value of close to $\$ 6$. Since they have a continuing need for shampoo, they are happy to buy two bottles of the defendant's product for a total of $\$ 4$. They would otherwise be willing to pay close to $\$ 10$ for these products. The consumer gets nearly $\$ 10$ worth of products for $\$ 4$, for a saving of $\$ 6$. A nd this is a real saving, because the consumer would otherwise pay $\$ 10$ for a competing product. The consumer is better off with the coupon settlement than with a cash settlement.

What about society? Society does not lose from a coupon settlement with the characteristics described above. ${ }^{52}$ A ssume that competitors are fully informed of the settlement. They will reduce their shampoo production by 2,000

52. We assume that the coupon settlement does not impose excess transactions costs that outweigh the efficiencies of the device. 
units, because they know they will be able to sell less as a result of the settlement. Competitors lose expected profits, but this is no more a social loss than is any competitive loss that results from a manufacturer providing a good more cheaply to consumers. The competitors can shift the resources that they would have otherwise devoted to manufacturing 2,000 bottles of shampoo to other productive uses.

O verall, social wealth is allocated more efficiently in this coupon settlement than in an immediate cash settlement. The losses suffered by consumers as a result of purchasing the defective product are sunk costs with no net wealth effects for the future. However, a coupon settlement may save various costs of the retail distribution chain, including advertising, inventory costs, and shelf space. If the consumer paid retail price in the future, these costs would be built into the price. These are real social costs that can be conserved through a coupon, as opposed to a cash, settlement. ${ }^{53}$

2. Monitoring Settlements. Monitoring settlements offer a number of potential economic advantages over immediate cash settlements in situations where a defendant's past actions are certain to impose harm on some, but not all, class members and it is impossible to predict at present which class members will suffer harm and how much. The defendant's monitoring can be a socially efficient way to identify harm if it should develop, and the damages paid after the harm occurs may be the most socially efficient distribution of a limited fund to the class. Those who develop harm will get proper treatment, while members of the class who retain health do not receive a payment.

What would be the result of the defendant giving the class an immediate cash settlement rather than intervening when harm develops? A cash settlement is not impossible in such a case: Experts could be retained to determine the likelihood of a given class member suffering harm and the probable cost to the plaintiff. Such testimony could, in theory, allow the settling parties to estimate the present value of the expected harm to all class members. E ach class member would receive a pro rata share of the fund, according to how likely it is that she would develop injury.

Class members might prefer to receive pro rata shares of the settlement fund if they are not risk averse. However, most people dislike risk, ${ }^{54}$ and we expect they will be risk averse especially in mass tort situations where the harms involved can be devastating illness. Hence, even if the expected payout by the defendant is the same, a medical monitoring approach may be more socially desirable than an immediate cash payout. Medical monitoring offers built-in insurance that if harm occurs, there will be money available to treat the injury. A cash payout would force the members of the plaintiff class to selfinsure against future harm, and acquiring this self-insurance would at the least

53. Of course, a full calculation of social costs would also have to include the costs of structuring and administering the nonpecuniary settlement itself.

54. See, e.g., RICHARD POSNER, E CONOMIC A NA LY SIS OF LA W 12-13 (5th ed. 1997). 
entail transactions costs. Such insurance might be unavailable in the private market, in which case class members who are injured might not have enough money to treat the injury, while the class members who do not become ill can use their damages for purposes unrelated to the defendant's conduct. H ence, if class members are risk averse, they may prefer, in effect, to purchase a built-in insurance policy with medical monitoring rather than to accept a cash payment and self-insure. ${ }^{55}$

$A n$ additional benefit of monitoring is that it encourages early diagnosis and treatment. In the absence of a monitoring program, members of the class may or may not obtain the necessary check-ups in order to detect harmful processes before they have advanced to the point where treatment becomes more expensive or impossible. ${ }^{56}$ A monitoring program can track persons known to face a particular risk of harm in order to identify symptoms when they first appear.

3. Securities Settlements: Stocks, P uts, and Warrants. A securities settlement may be favored over an immediate cash payout if the present value of the securities settlement is at least comparable to the cash the class could realistically obtain, and the securities settlement is less costly for the defendant than obtaining the necessary liquidity to make a cash payment.

If the defendant has the cash on hand to pay the settlement, then payment by cash ordinarily should be favored over issuing securities. A cash settlement would usually be preferable from the standpoint of the corporation because it is less costly than a securities settlement. Stock settlements have the transaction costs associated with filing registration statements and the potential liabilities that attach to securities issues. These costs are absent in a cash settlement. There may also be costs to class members. They may not want the company's securities in their portfolio and will have to incur the costs of selling the securities and putting the proceeds to other uses.

There are circumstances, however, when a defendant has little cash on hand and a securities settlement might be the most efficient means for the defendant to obtain a release from liability. The securities settlement does not require the defendant to obtain the necessary liquidity to make a cash settlement.

Consider the following two settings. First, a corporation may be close to insolvency and lack the resources to make a cash payment. In such a case, the defendant will find it impossible, or nearly so, to access the capital markets to ob-

55. It might be efficient if the settlement gave class members the option to accept a cash payout as an alternative to monitoring relief. However, class members are unlikely to be well informed about the probability and cost of harm they are facing, and may accordingly accept a cash-out option too readily. M oreover, the take-up rate on a cash option may be so high as to reduce the number of members remaining in the monitoring program, thus decreasing the efficiency of the monitoring if, as seems likely, there are increasing returns to scale in this activity.

56. In the medical setting, the advantages of regular screening for certain diseases are well known and thoroughly documented in the literature. See, e.g., Carswell \& Fleming, Whole Population Screening for Carriers of Cystic Fibrosis, 347 THE LA NCE T 1421 (1996); S. Field et al., What Should be D one A bout Interval B reast Cancers? Two View Mammography and a Possibly Shorter Screening Interval, 310 BRIT. MED. J . 203 (1995). 
tain the necessary liquidity to pay out claims. By issuing stock, puts, options, or warrants, the corporation can provide a form of relief with real value. If it has to give cash, the company might be forced into bankruptcy and class members as nonpreferential creditors might not receive compensation.

Second, a corporation with limited cash on hand may have managers with private information about the value of the company that is not widely known in the market. Managers with such information might prefer to avoid going to capital markets to raise funds for a cash payout to class members because they believe that the company would have to pay more for the necessary liquidity than it would pay if the market were fully informed about the company's prospects. A securities settlement eliminates the need for a defendant to raise funds for a cash settlement. The class members in effect become investors in the corporation. Since the corporation, in this example, is undervalued in the market, a securities settlement saves on capital formation costs. These savings can be shared between the defendant and the class. E ven if a corporation does not need to go to capital markets to fund a cash settlement, but rather uses treasury funds, the reduction in cash on hand could inhibit the corporation's ability to pursue future value-enhancing projects, thereby lowering the present value of the company. Diluting stock value so there are more outstanding shares would not have this effect.

Special problems arise when the class includes a large percentage of the company's existing shareholders. In the limiting case, the only class members will be all the company's shareholders and the only defendant will be the company itself. Here, a stock settlement would be functionally identical to a stock dividend to shareholders. All shareholders would have their stock diluted in proportion to their share ownership. In such a case, no shareholder would be relatively better off as a result of the settlement, while the company would have had to incur the costs of litigation and of issuing the new shares. The plaintiffs' attorneys would skim off value in the form of fees. Such settlements might conceivably be justified as a method for imposing a fine on a corporation for socially undesirable actions, but it is doubtful that the social benefits would exceed the costs. In most cases, however, the intersection between the class members and the existing shareholders will be much smaller, and there will be other defendants - notably incumbent managers - from whom relief can be obtained.

4. Reverter Funds. A reverter fund can be economically efficient if an immediate cash payment to the class is impractical. The fund is held by an escrow agent and is protected against invasion by the defendant's management as well as against the claims of defendant's creditors. A reverter fund can be desirable when it is costly for the class to monitor the defendant's finances to 
ensure that the money owed the class is not spent for other purposes. ${ }^{57}$ Reverter funds provide assurance to class members that their claims will be paid, at least up to the limits of the fund. ${ }^{58}$

The utility of reverter funds appears to be a function of two variables. O ne is the duration of the claims period. When the payout period extends over a long period of time, there always is a danger that business conditions will deteriorate or the corporation will be mismanaged, resulting in future insolvency. A s the period between settlement and payout to class members lengthens, the probability of intervening insolvency increases, and the case for a separate escrow fund becomes stronger. The other variable is the solvency of the corporation at the time of settlement. If the company is in shaky financial condition, it may be sensible for the parties to endow a separate fund in order to protect those assets from other creditors, even if the period of payout is fairly short. Such funds would presumably withstand claims by creditors of an insolvent defendant as long as the transfer complies with the rules of federal bankruptcy law.

5. Fluid Recovery Settlements. Fluid recovery settlements can be economically desirable when the class is large and many members of the class cannot be identified or are unlikely to file a claim. E ven if some members of the class do receive direct compensation from the defendant, the unidentified or nonclaimant class members can obtain some benefit if the settlement reaches them indirectly. A fluid recovery typically provides this sort of indirect benefit. For example, the defendant may agree to reduce the price of a product that members of the class will purchase.

The fact that nonclass members also benefit is not an objection to fluid recoveries. In a well-structured fluid recovery settlement, because the defendant must pay an amount at least equal to the amount the defendant would have to pay if class members could readily be identified, the deterrent effect of a fluid recovery can be the same as a cash recovery. Further, to the extent that the nonclass recipient of the funds is an efficient user of the resources, society can benefit from the transfer. Thus, with a fluid recovery, the defendant is deterred from wrongful behavior in the future, class members who can not be identified may receive some degree of reimbursement for their injury, and other members of society may gain something of value as well.

57. M onitoring advantages are one of the principal reasons found in the literature for why a borrower and lender would agree to collateralize a loan. See, e.g., R onald J. M ann, Explaining the Pattern of Secured Credit, 110 H A R V. L. R E V. 625, 650-51 (1997).

58. The members of the class will benefit if the fund is fully endowed with an amount sufficient to pay out all claims, with any amounts left over at the expiration of the claim period to be refunded to the corporation. However, there may be little justification for the creation of funds larger than the largest amount reasonably expected to be paid out in claims, since such funds tie up corporate assets. If the fund does get used up, the remaining class members could get their recovery directly from the defendant. 
$\mathrm{V}$

\section{Sa feguards a Ga Inst Undesirable Nonpecuniary Settlements}

The litigation process may provide inadequate checks on the incentives which may cause entrepreneurial plaintiffs' attorneys and defendants to settle a case non-optimally for the class. J udicial scrutiny of a proposed nonpecuniary settlement may not always be searching. If both the plaintiffs' attorneys and the defendant want the settlement approved, they will not supply the judge with information that shows that a different settlement could have been obtained giving more to the class but less to class counsel. The judge has nothing to compare the settlement with, and the judge would prefer to settle the case than have it continue on her docket. The judge has before her plaintiffs' and defense counsel vigorously supporting the settlement. Her decision approving the settlement has little chance of reversal, both because there may be no one to appeal, ${ }^{59}$ and because the standards for judicial review of settlement approval are very deferential. ${ }^{60}$ While judicial review of settlements is essential, and capable trial court judges often perform an important public service in this context, judicial review can usefully be supplemented by a variety of other mechanisms that tend to validate the fairness and adequacy of a nonpecuniary class action settlement.

In this section we consider the utility of several of these safeguards, including repeat player law firms, objectors, cash-out provisions, and the presence of an alternative dispute resolution mechanism for class members.

\section{A. R epeat Players}

One safeguard against undesirable nonpecuniary settlements is the role large firms play as plaintiffs' counsel. Our empirical research demonstrates that certain firms appear frequently in class action settlement notices published in The $\mathrm{N}$ ew $\mathrm{Y}$ ork Times. B y far the leading firm is $\mathrm{M}$ ilberg $\mathrm{W}$ eiss B ershad $\mathrm{H} \mathrm{y}$ nes $\&$ Lerach, which appears in approximately a quarter of all the cases in the sample. ${ }^{61}$

The repeat-player firms such as Milberg W eiss can have an important role in policing against settlements that benefit the defendant at the expense of class recovery. R epeat player firms are experienced in class action cases, and can be expected to represent class members with a high degree of competence. No large firm is likely to be tricked into a settlement that serves only the benefit of the defendant. Further, large firms have the resources to conduct litigation over the long haul (for example, by paying notice costs and travel costs), and therefore present a credible threat that if the case does not settle, they will be

59. However, see infra text accompanying notes 63-65 on objectors.

60. A bsent abuse of discretion, the appellate court will not substitute its judgment for that of the trial court. B ut see General M otors Corp. v. B loyed, 916 S.W. 2d 949 (1996) (affirming the appellate court's ruling that the trial court did abuse its discretion in approving a settlement).

61. See A pp. I, part A. 
willing to conduct full discovery and take the case to a jury. The fact that most class actions do settle does not mean that large firms present no credible threat to take the case to the trier of fact. A case may settle because the defendant believes that the large firm is able to take the litigation to trial, and therefore is willing to offer more in settlement in order to reduce its exposure. Thus, repeat player firms can provide a significant benefit for class members by virtue of their expertise, reputation, and capitalization. Of course, large firms also have an economic incentive to enter settlements that benefit them at the expense of the class, but this incentive is shared by all plaintiff firms, large or small, and large firms can be expected to be no worse with respect to the interests of class members than are small firms.

M ore subtly, repeat player law firms guard against the reverse auctions that may cause plaintiffs' attorneys to settle a case for too little in order to obtain the case for themselves over attorneys litigating in another jurisdiction. Because these reverse auctions can generate nonpecuniary settlements, the presence of $\mathrm{M}$ ilberg $\mathrm{W}$ eiss and other repeat player firms provides a potential check on this danger. M ilberg W eiss and a few of its peer group firms have the resources, knowledge, expertise, and financing to appear in virtually every jurisdiction in which a class action is brought. Once they have appeared, they have the clout with their fellow class action attorneys either to become lead counsel or, at least, to exercise influence on whatever firm is selected for that role. M ilberg W eiss's presence in all the jurisdictions where a class case is pending thus acts as a counterweight to the danger of a reverse auction. E ven if M ilberg Weiss is not in a particular jurisdiction, the firm is important enough in the plaintiffs' bar that it could exact a future sanction against any plaintiffs' firm that engaged in a "sell out" settlement of a case.

\section{B. Objectors}

R ecently, objectors have become a major force in class action settlements, in part because such settlements are often controversial, and in part because objectors sometimes earn a great deal of money by intervening. ${ }^{63}$ O bjectors are particularly likely to appear when the litigating parties propose nonpecuniary settlements, because the settlement will nearly always be vulnerable to the objector challenging the valuation of the settlement.

O ne might suppose that, whatever the motives of objectors, ${ }^{64}$ their impact on judicial review of settlements can only be positive; they will bring defects in

62. For example, M ilberg W eiss could use its power as lead counsel to deprive the offending firm of remunerative work in future cases.

63. A Wall Street J ournal article recently chronicled some of the fees obtained by objectors in large class actions. See R ichard B. Schmitt, O bjecting to Class-A ction Pacts Can Be L ucrative for Attorneys, W A LL ST. J., J an. 10, 1997, at B 1. In one case, a mediator had originally recommended that the lawyers who filed an objection be paid $\$ 400,000$, but when the objectors appealed the settlement, class counsel upped the ante to $\$ 1$ million whereupon the appeal was dropped. See id.

64. Some objectors are simply uninformed class members who write to the court, or, less commonly, appear during the settlement hearing, to voice opinions having little relevance to the matters 
the settlement to the attention of the court, and may enhance the settlement for the benefit of the class or reduce the plaintiffs' attorneys' fees that class members might have to pay. It may appear that objectors act as a safeguard performing a useful service by subjecting nonpecuniary settlements to adversary testing, thus calling the court's attention to adverse features of the settlement that counsel for the settling parties wish to disguise. Objectors do, indeed, sometimes obtain improvements in settlements, although in the majority of cases, objectors fail to alter the terms of the original proposal. ${ }^{65}$

$\mathrm{H}$ owever, this perspective ignores a number of factors. First, the objection itself has costs, because the objector, to make his or her threat credible, may at-

under consideration. For example, it is not uncommon for class members to object to the settlement on the ground that they believe the defendant has done nothing wrong-a commendably loyal opinion, but one with no relevance in a settlement hearing.

A second class of objectors includes dissident plaintiffs' attorneys who have fallen out with lead counsel. The threat to object to the settlement is always a factor in the negotiations among the attorneys in the plaintiffs consortium. If these negotiations break down, the loser sometimes carries through with the threat. The true basis of the objection is nearly al ways the fact that the objecting attorney believes that he or she is not receiving sufficient compensation from lead counsel on the plaintiffs' side. However, unless relations among the attorneys in the plaintiffs' consortium have broken down altogether, the dissident attorney usually hopes for an increased fee in return for dropping the objection. A ccordingly, the dissident attorney is likely to be deterred from pointing out fatal defects because to do so might destroy the settlement from which the attorney still hopes to obtain a fee.

A third class might be termed "sokaiya" objectors. Sokaiya are figures in J apan who specialize in disrupting shareholders meetings by complaining loudly about management's alleged incompetence or poor performance. See DAVIDE. Ka PLAN \& A LEC DUBRO, YAKUZA: ThE EXPLOSIVE A CCOUNT OF J A PAN'S CRIM INA L U NDER WORLD 172-73 (1986). M ark West describes the problem as follows:

These rent-a-thugs, or as they prefer to call themselves, "professional shareholders," began to perfect their blackmail techniques, which now take a variety of forms. Some sokaiya groups call themselves "consulting groups" or "research institutes" and engage in the collection of "corporate data." This "data," which usually consists of intimate details about the personal lives of management, is sold to the company for an exorbitant "consulting fee." M ore inventive hoods have perfected the art of making offers that management can't refuse. These sokaiya groups arrange beauty contests that companies are strong-armed into sponsoring, organize golf tournaments with excessively high entrance fees for Tokyo businessmen, and host kabuki plays at which ticket prices cost five times their normal price.

M ark D. W est, The Pricing of Shareholder D erivative A ctions in J apan and The U nited States, $88 \mathrm{~N} \mathrm{w.}$ U. L. REV . 1436, 1451-52 (1994). Class action practice in the U nited States has developed its own cohort of professional objectors: attorneys who enter a case after a settlement is announced, manage not only to object to the settlement but to intervene as counsel on behalf of a class member, and then threaten to disrupt the settlement unless they are given a hefty reward. Their threat is not an idle one. A s long as they can intervene, they can appeal the settlement as of right, and during the appeal process, the settlement will be in limbo. Class counsel will not be paid and class members will not receive their benefits. The prospect of delaying a settlement for months or years by taking an appeal is the realistic threat that objectors hold over the heads of the settling parties. These days, professional objectors can include, not only private attorneys, but also, in some cases, state A ttorneys G eneral who see the political and economic benefits in claiming public credit for reducing counsel fees or enhancing class settlements. O bviously, the term "sokaiya" for this type of objector is used here in a tongue-incheek fashion; professional objectors to class action settlements are attorneys in good standing who utilize perfectly legal means to contest settlements, and have no criminal intent.

In addition to the first three categories of objector we have identified-uninformed class members, dissident plaintiffs' attorneys, and sokaiya objectors-there are institutional investors, public interest groups, individual attorneys, and others who make a bona fide attempt to improve the settlement.

65. The Federal Judicial Center study, for example, found that in cases where objections were filed, more than $90 \%$ of the settlements were approved without change. See FEDERAL JUD. CENTER, supra note 16 , at 58 . 
tempt to engage in discovery related to the settlement and may even attempt to take depositions of counsel or their experts. Second, threats are never effective unless they are occasionally exercised. O bjectors will therefore sometimes appeal class action settlements. A ppeal of a class settlement is unlikely to be successful, given the large discretion enjoyed by trial courts in assessing their fairness. But the appeal process is costly and, above all, will delay the award of relief to class members.

Perhaps most troubling is the ex ante effects of objections. These days, when parties negotiate any major class settlement, especially one involving nonpecuniary relief, they expect to see objectors appear. They anticipate, therefore, that they may have to change the terms of the settlement in order to satisfy objectors. In consequence, they are likely to adjust the settlement proposed to the court to allow a margin for satisfying objectors while ending up with the same settlement they would have reached had objectors not played a role. Suppose for example that if the parties know no objector will appear, they will reach a settlement equal in value to $\$ 1,000$ for the class and an attorneys' fee of $\$ 200$. If they know, however, that an objector is waiting in the wings, ready to intervene and threaten an appeal of any judicial order approving the settlement, instead of proposing the settlement in the absence of an objector, they propose a settlement equal in value to $\$ 800$ and an attorneys fee of $\$ 300$. Now when the objector appears, they can adjust the settlement as a purported compromise that sweetens the deal for the class by agreeing to raise the class relief to $\$ 950$, drop the attorneys' fee to $\$ 200$, and pay the objector $\$ 50$ for his or her services:

\begin{tabular}{|lccc|}
\hline R ecipient(s) & $\begin{array}{c}\text { Settlement 1 } \\
\text { (without objector) }\end{array}$ & $\begin{array}{c}\text { Settlement 2 } \\
\text { (expecting objector) }\end{array}$ & $\begin{array}{c}\text { Settlement 3 } \\
\text { (after objection) }\end{array}$ \\
\hline Class & $\$ 1,000$ & $\$ 800$ & $\$ 950$ \\
Class counsel & $\$ 200$ & $\$ 300$ & $\$ 200$ \\
Objector & & & $\$ 50$ \\
\hline
\end{tabular}

In this example, settlement 3 , the end of the process of objection, is inferior from the class's perspective to the settlement that would be reached if no objection were anticipated. It is also inferior from a social point of view, both because class members do not receive the full compensation they could under settlement 1 , and because it provides an incentive for objectors to appear whose only function ex ante is to increase the transaction costs of the settlement and to expropriate a portion of its value.

Notice, moreover, that the process has several other undesirable features. First, it is possible that no objector will appear. If no objector appears, the litigation will culminate with settlement 2 , which is even less desirable from the class's point of view than settlement 3 (the class obtains only $\$ 800$ in relief rather than \$950), and which represents a windfall for plaintiffs' counsel who anticipated an objection and did not receive one. Second, the process of objec- 
tion itself tends to validate the settlement. It might appear that, given a settlement that has been proposed, objected to, and sweetened, the settlement has undergone appropriate adversarial testing and, in the process, been improved so as to be fair to the class. The example shows that this is not necessarily the case.

\section{Cash-out Provisions}

Cash-out provisions can mitigate some of the problems we have identified with nonpecuniary relief, especially in the case of coupon settlements. Cashout provisions place a floor on the cash value of the settlement, and provide an option to persons who will not take advantage of the nonpecuniary relief. It is not necessary that the cash-out provision be as valuable as the stated or par value of the nonpecuniary relief. Indeed, the cash-out relief ought in every case be less than the available nonpecuniary relief; otherwise many class members would elect the cash option and the efficiency benefits of nonpecuniary relief would be lost.

For the cash-out provision to be effective, the settlement should not impose unduly burdensome conditions on class members wishing to exercise it. If too many conditions are placed on the cash-out option, the transaction costs of the option will make it too costly to be worth exercising. A $n$ example of seemingly onerous conditions is found in the Computer $M$ onitor Cases settlement. ${ }^{66}$ The settlement provides that class members have a right to a $\$ 6.00$ cash payment instead of a coupon for a $\$ 13.00$ rebate on the purchase of new equipment. However, the fine print of the settlement states that the cash payment can be obtained only if the class member submits a completed rebate form at the end of the rebate period. The rebate period expires on September 8,2000 . It is unlikely that many class members will keep their rebate forms and submit them for $\$ 6.00$ in cash after the turn of the century — not only because six dollars three years from now is worth less than six dollars today, but because people are likely to lose or forget about their coupons.

\section{A D R Procedures}

R ecently, a number of nonpecuniary settlements have appeared with an alternative dispute resolution ("ADR") feature, which is available to any class member who does not want to accept the general class relief. ${ }^{67}$ The ADR program sets up a form of arbitration with an expedited and inexpensive evidentiary process, using a variety of presumptions to aid in fact-finding. U nder the terms of the A D R procedure, plaintiffs who manage to satisfy a variety of relatively simple presumptions are entitled to relief that potentially exceeds the

66. See supra note 22 and accompanying text.

67. A $n$ example is the settlement in M ichels v. Phoenix Home M ut. Ins. Co., Index N 0. 5318- 95, N.Y. Sup. Ct. (County of A lbany), Notice of Settlement, M ay 1997, published in N.Y. TIMES, May 1997. Class members could take a form of coupon settlement offering them general policy relief on whole or universal life policies, or they had the option of taking advantage of an A D R procedure. 
value of the relief which they would be entitled to as members of the class under the general nonpecuniary settlement.

The ADR procedure is a valuable option that can provide class members with some kind of hearing, and enhanced relief, without requiring them to opt out of the settlement and bring their own separate litigation. D epending on how it is structured, ADR can mitigate some of the problems with nonpecuniary settlements. To work adequately, the ADR process should provide for streamlined procedures that still take account of the differences in individual cases and allow a degree of individualized adjudication before a neutral arbitrator, with the prospect of more favorable relief at the end of the process for those parties who are able to establish that they have stronger-than-average claims.

However, two potential downsides of ADR must be noted. First, if the $A D R$ is too favorable compared with the general class settlement, the take-up rate of the ADR may be so great that it vitiates the benefits of the nonpecuniary relief, which depend in part on the efficiencies of a pre-formed class of persons with similar interests. Second, ADR procedures have a built-in adverse selection problem in cases where the strength of claims varies substantially from member to member. The class members with stronger claims may tend to select out of the nonpecuniary relief into the ADR process where they are likely to receive a more favorable settlement, leaving those persons with the weaker claims to take the nonpecuniary award. The parties may then reduce the value of the general relief, taking into account that weaker claims will be remaining after some members have elected to proceed via ADR. B ut weakening the general relief increases the likelihood that class members will opt out of the settlement entirely or will elect to use the ADR process. This recursiveness may make it hard to structure an effective A D R program in nonpecuniary cases.

\section{VI}

\section{StandaRds FOR J UDICIA L REVIEW OF NONPECUNIARY SETTLEMENTS}

Courts currently review nonpecuniary settlements according to the same standard as cash settlements: Is the settlement fair, adequate, and reasonable? This test becomes difficult to administer in the nonpecuniary setting because of the valuation problems already discussed. To clarify analysis, courts engaging in fairness review of nonpecuniary settlements should apply a cash equivalency test: Is the settlement under consideration as good or better, within a range of reasonable error, for the members of the class than what realistically could be expected in a cash settlement?

Three general points are pertinent at the outset. First, it is evident that some parts of this test are open-ended and subject to interpretation. For instance, in evaluating whether a nonpecuniary settlement is "as good or better for the members of the class than what realistically could be expected in a cash settlement" the court could decide to look at the settlement's expected value to 
the entire class and compare that value with a cash settlement, or the court could look at the median value to the class and ignore outlier effects. In this manner, the cash equivalency test can and should be fleshed out by judges in the context of deciding actual cases.

Second, we emphasize that the relevant comparison is not between the actual value of the nonpecuniary settlement and its par or stated value. It is obvious that nonpecuniary settlements usually will be less valuable to the class than the face value of the settlement. Instead, the proper comparison is with the amount of any cash settlement that realistically could be expected from the litigation. If the expected actual value of the nonpecuniary settlement is as good or better than the realistically available cash settlement, the judge can conclude that the nonpecuniary settlement is in the best interest of the class and should be approved.

A third consideration is that the comparison between the nonpecuniary settlement under review and the hypothetical best available cash settlement must be made within fairly broad margins of error. Ordinarily, the court will not have access to precise and reliable information about what cash settlements would have been available had the parties followed that route. A court applying the test must make its judgment based on the best information available, which is unlikely to resolve the issue with precision. ${ }^{68}$ Trial court discretion should be exercised wisely in adjudicating the desirableness of a particular nonpecuniary settlement using the cash equivalency test.

What follows is a series of factors that might be evaluated by courts reviewing each type of nonpecuniary settlement. The suggested factors help analyze whether the nonpecuniary settlement meets the requirements of the cash equivalency test.

\section{A . Coupon Settlements}

In reviewing a coupon settlement, the court should consider whether the defendant is saving on transactions costs of marketing and distributing goods or services to customers, and, if so, whether some of those savings are passed on to the class. This is an indication of an efficient settlement. A mong the most important factors for the court to consider are the following:

1. To what extent is the good or service covered by the coupon one that members of the class might want to purchase? If the item is usually purchased

68. However, there may be some evidence on the issue. For example, the parties may have considered a cash payment during the course of their settlement negotiations. If so, the amounts of cash consideration offered or demanded would be relevant considerations-along with the court's assessment of the degree to which negotiations over a cash settlement were serious and in good faith. The parties may have performed independent appraisals of the cash value of the case ex ante, which would be relevant although not dispositive given the fact that such appraisals may be conducted before discovery. Expert witnesses could be enlisted to offer testimony on the reasonable cash value of a settlement as compared with the value of the nonpecuniary relief actually obtained. A nd trial courts with experience in litigation can often bring a practiced eye to bear on the settlement in order to assess whether the nonpecuniary relief is as good or better than what could have been obtained in cash. 
on a one-time basis, this should count against the reasonableness of the settlement. On the other hand, if the item is something that most members of the class purchase on a fairly regular basis, this should count in favor of the settlement.

2. To what extent does the good or service have idiosyncratic features that make it a poor substitute for products offered by others? For example, many people use perfume or cologne, but for most consumers, brands of scent are not fungible. The scent a consumer uses is a personal choice, and it would not be useful for a consumer to receive a coupon to purchase a perfume that she does not use. (However, if the consumer already has indicated a preference for a brand by an initial purchase that went bad, that brand may still be the preferred scent and be a brand the consumer would purchase again.) On the other hand, most car owners do not have strong preferences about the brand of tire they use, so long as they obtain the qualities they desire in terms of durability and performance. To the extent that the desirability of the item covered by a coupon settlement depends on personal idiosyncrasies, the item is less desirable for coupon treatment; on the other hand, if consumers will accept substitution of brands, the item will be more appropriate for coupon treatment.

3. How soon is the average class member likely to use the coupon? If customers are likely to use their coupons quickly, this weighs in favor of the settlement. On the other hand, if the item requires replacement infrequently, this will count against the usefulness of a coupon. If there is a long delay before using the coupon, consumers may lose, misplace, or forget about them.

4. How long are the coupons valid? For items that are frequently purchased, a fairly short claim period would be appropriate in order to reduce the costs of administering the settlement. If items are not frequently purchased, an abbreviated claim period may be unreasonable because the coupon may have expired by the time a class member needs the item.

5. To what extent are coupons transferable? If the settlement allows free transfer of coupons, this counts in favor of approval. If some restrictions on transfer are in place, these may be justified as necessary to protect the defendant against the risk of sudden and unforeseen redemptions, affording a higher degree of reliability in estimating the take-up rate. Severe restrictions on transferability usually counsel against approval except in unusual circumstances, because such restrictions reduce coupon utilization and discriminate, within the class, between members who have a use for the product and ones who do not.

\section{B. Monitoring}

When members of the class cannot determine whether they have suffered harm from the defendant's actions, monitoring settlements offer potential benefits. The court should focus on two areas. First, are class members risk averse and is insurance costly? If so, a monitoring settlement may offer a form of built-in insurance with low transactions costs. Second, will monitoring per- 
mit early diagnosis and treatment of medical or product-related harm? This can save lives or reduce costs. M ore specifically tailored factors include:

1. To what degree are class members risk averse with respect to the harm involved? If the harm is only slight, the class members may not be particularly risk averse, whereas if the harm is severe _as in some medical monitoring cases in which the class members are at risk of devastating physical illness - the presence of risk aversion can easily be inferred. The greater the risk aversion among class members, the greater the utility of monitoring as compared with cash relief.

2. To what degree is insurance readily available to class members to cover the risks involved? If class members can readily obtain insurance in the market, it may be better to award them a cash settlement and allow them to obtain the amount of insurance that, in view of their own tastes and preferences, they desire. On the other hand, if insurance is costly, the case for monitoring becomes stronger.

3. How likely is it that the class members will suffer the harm for which relief is sought? This factor is somewhat complicated, because monitoring appears most appropriate when the risk of harm is in an intermediate range. When the risk of harm is large, monitoring may not be required for riskreduction purposes because one can predict that the class member will suffer the harm. In the limiting case, if it is known that all class members will suffer a harm of $\$ 1,000$ within two years, it hardly makes sense to institute a monitoring program. Because everyone will suffer the harm, it would make more sense to provide them with an immediate cash payment. Similarly, when the risk of harm is very slight, monitoring may not be appropriate because the costs of monitoring may outweigh the savings obtained. However, when the risk of harm is in the intermediate range, such that class members have a significantly above-average probability of suffering a particular condition, monitoring is likely to be valuable.

4. How predictable is the timing and extent of harm if it occurs? In some cases, it may be possible to predict when a class member will suffer harm, and how great the harm will be. When damages are predictable, there is relatively less reason to institute a monitoring program in order to reduce risk because harm that occurs within a definite time period is less risky than unpredictable harm.

5. To what degree can early diagnosis and treatment reduce the costs of harm? If early diagnosis and treatment can significantly reduce costs, there is a strong case for monitoring. On the other hand, if early diagnosis and treatment can do little to alleviate the harm or economize on treatment costs, the case for monitoring is correspondingly weaker.

\section{Securities Settlements}

With respect to securities settlements, the court should consider the following factors: 
1. Is there evidence that the defendant's cost of capital makes a securities settlement more valuable to the class than a cash settlement? If the defendant is in shaky financial condition, a securities settlement might be desirable because the defendant would have to pay a risk premium in capital markets to raise the money for a cash settlement. This leaves less money available for the class out of the sum total devoted to settlement funds. Similarly, if the defendant's management has nonpublic information about the firm that indicates that its cost of capital is higher than it would be if the market were fully informed, this factor might counsel in favor of a securities settlement since some of the defendant's savings in capital formation could be passed on to the members of the class. ${ }^{69}$

2. Is the security involved listed and traded on a developed market? If it is, the security can be valued and compared to a potential cash settlement. $M$ oreover, provided there are no transfer restrictions in place, the presence of a ready market allows holders to liquidate their positions if they prefer to invest in some other asset or use the value of the settlement for consumption. However, restrictions on transfer may be justified by business or legal reasons; for example, if the stock is issued as an offering exempt from registration under the securities law, there may be good reason to impose restrictions on resale. ${ }^{70}$ In deciding if a restricted transfer securities settlement is desirable, the court should balance the costs to the class of the restrictions on transfer against the costs to the defendant of paying a cash settlement.

3. What happened to the price of the company's stock in public markets around the time the potential settlement was announced? If the market's expectation of the settlement value bears a relationship to the value of the case, which would be expected in an efficient and well-informed market, then the market's reaction to the announced settlement could be an indicator as to whether the settlement is equivalent in value to the best available cash settlement. ${ }^{71}$ O ther things equal, if the company's existing stock goes down relative to the market, it can be inferred that the settlement exceeds the market's expectations. If, on the other hand, the defendant's stock goes up relative to the market, one might infer that the market was expecting a more expensive settlement and was pleasantly surprised by how cheaply the company was able to purchase a release from liability.

69. However, it may be difficult to establish the existence of such nonpublic information when the defendant's stock is trading on a developed stock market such as the N ew Y ork Stock E xchange.

70. It should be noted that the class member may lose less from a restriction on resale of stock if the company is expected to stay in business than from a similar restriction on transfer of a coupon in a coupon settlement. The stock will remain indefinitely in the holder's portfolio, whereas the coupon may never be used and may eventually become worthless.

71. While share price effects are important, however, they should not be overestimated. It is far from clear that the market operates in an efficient manner with respect to litigation risk- especially given the confidential nature of much of the information involved in litigation. The performance of the company's stock in response to an announced settlement, even if it is informed, will reflect only the market's assessment of the difference between the predicted settlement and the settlement actually reached. This does not necessarily indicate that the settlement is fair. 


\section{R everter Funds}

In the case of reverter funds, one might suppose that the court should have no objection to the creation of a pool of money that can help the class by securing payment of the defendant's obligations. H owever, the creation of a reverter fund is not necessarily an efficient method of class compensation. In creating the fund, the defendant ties up capital that it might want to use for other profitable investments. If the defendant would be better off not tying up capital, and the class members would be well secured in any event, then it might be less desirable for the parties to establish a fund than for them to provide for payment directly from the defendant. R everter funds also may be undesirable to the defendant if the court awards attorneys' fees on the percentage method and calculates the percentage on the basis of the entire value of the fund, rather than on the amount claimed by the class. A court considering this type of relief should determine whether the parties have good reasons for providing this sort of security to the class members:

1. How extended is the claim period? If the claim period is brief, the need for a segregated fund may be small, because there is a low probability that the defendant will become insolvent or use the money for investment and make the class members wait for payment. If the claim period is extended, however, the case for a segregated fund is stronger, because as the time between settlement and claim grows larger, there is a greater risk of insolvency or other intervening cause harmful to the plaintiffs.

2. How strong is the defendant's financial condition at time of settlement? If the defendant is in shaky condition, the class may obtain a substantial benefit from the creation of a segregated fund immune from the claims of defendant's other creditors. If, on the other hand, the defendant is well capitalized, there is relatively less cause to establish such a fund.

3. How much is in the fund relative to the amounts of potential claims? If the fund is insufficient to satisfy claims reasonably expected during the settlement period, it may offer little benefit and, indeed, may be harmful because class members may be misled by the existence of a fund into believing that their claims are fully secured when in fact they are not. On the other hand, if the fund is grossly in excess of the amount class members can reasonably be expected to claim, a court might be concerned that the fund was established in order to create a high valuation for the recovery, and thereby to increase the fees of class counsel at the expense of the class.

\section{E. Fluid R ecovery}

In evaluating the desirability of a fluid recovery class settlement, the court should consider whether individualized relief is feasible and if so, at what cost to the defendant. A Iso, the court should ask if fluid recovery is a better deterrent to the defendant and others similarly situated than individualized relief. Considerations include the following factors: 
1. How difficult is it to locate class members? If class members would be hard to identify, the court should consider whether a fluid recovery would be preferable from a social viewpoint than individualized recovery. Since fluid recovery exacts the full settlement amount from the defendant, this technique can optimally deter the defendant; if many class members can not be located, individualized relief imposes less deterrence on the defendant.

2. Who will be the noninjured recipients of the fluid recovery? A ssuming the fluid recovery either supports a price decrease, or is used to fund research or education, it is likely members of the class will not be the only people to benefit from the fund. The fund should not be controlled by plaintiffs' attorneys, because the money may be directed to causes that benefit the attorneys' interests, rather than the best interests of the class or other people in similar situations. On the other hand, fluid recoveries can provide some benefits to injured class members who do not receive compensation directly. The court should evaluate the proposed relief with a realistic sense of what can actually be achieved in the circumstances of the case.

3. If individual class members can be identified, are there onerous or confusing prerequisites the members must comply with in order to obtain relief in the absence of a fluid recovery? If facilitating individualized class recovery requires claimants to supply detailed information that most people either have not maintained or do not have at hand, the inconvenience or impossibility of complying with settlement requirements will reduce the number of claimants and exclude legitimate class members from recovery. However, if the requirements are designed to assure against fraudulent claims, then some amount of inconvenience to class members may be acceptable; if the cost of inconvenience is too high, then the class will not benefit from the recovery and a fluid recovery may be the desirable form of settlement.

VII

\section{CONCLUSION}

This article has provided an analysis of nonpecuniary class action settlements: coupons, securities, monitoring, reverter funds, and fluid recoveries. It provides economic arguments for and against these settlements. The argument against is well understood in the literature; it is based on the theory that class counsel operating as entrepreneurs can enrich themselves at the expense of the class by manipulating the settlement into a nonpecuniary form which, because it is difficult to value, can be passed off as more beneficial to the class than it actually is.

The arguments for nonpecuniary class action settlements are less well understood. We suggest that each of the forms of nonpecuniary relief can be justified on economic grounds, at least in theory, as a means for providing benefits to the defendant or the plaintiff class that can be shared between the settling parties, making both sides better off. M oreover, nonpecuniary settlements can utilize the built-in structure of the class action to enhance these benefits. Cou- 
pon settlements provide a potentially efficient means for marketing goods and services to consumers that conserves on costs such as inventory, advertising, and distribution. M onitoring settlements have two economic advantages: They reduce risk for class members relative to cash settlements, and may conserve social resources and minimize harm by offering the potential for early diagnosis and treatment of harmful conditions. Securities settlements offer efficiencies in the capital formation process. R everter funds provide a form of security to class members that protects their benefits against invasion either by the defendant or by its creditors. Fluid recoveries can be an efficient means for deterring corporate misconduct when class members entitled to relief are difficult to identify on an individual basis.

We suggest that there are safeguards in the litigation process that may protect the class from abuse of nonpecuniary settlements. It is a positive factor if one or more of the larger class action firms is present in court on the plaintiffs' side, because these firms offer a combination of expertise in class action practice, a reputation to uphold, and the ability to resist reverse auctions by defendants who seek to bargain among competing teams of plaintiffs' attorneys. The presence of a cash-out option, provided that the option is a real one and not freighted with conditions that make it so inconvenient as to be worth little, is also beneficial. A Iternative dispute resolution procedures can be valuable supplements to nonpecuniary settlements if they are not unduly burdensome and are structured to avoid adverse selection problems in the structure of the basic nonpecuniary relief. However, despite the apparent benefit they offer the class and the court by bringing adverse aspects of the settlement to the attention of the judge and sweetening deals from time to time, objectors may actually offer little to the settlement process because of ex ante effects and the incentives that objectors have in the process.

The judicial analysis of nonpecuniary settlements should be based on a formula of cash equivalency: Is the settlement under consideration as good or better, within a range of reasonable error, for the members of the class than what realistically could be expected in a cash settlement? We suggest a number of factors that a court may consider in evaluating the fairness, adequacy, and reasonableness of settlements under the cash equivalency test. These considerations are specific to the particular form of nonpecuniary relief in issue; the relevant factors bear on the question whether the relief being proposed offers the prospects of real savings in economic efficiency, compared to an immediate, allcash settlement to injured class members. 


\title{
A PPENDIX A
}

\author{
EMPIRICAL DATA
}

\section{A. A n E mpirical O verview of N onpecuniary Settlements}

For a number of reasons it is difficult to assess the importance and frequency of nonpecuniary settlements on a statistically reliable basis. Settlements are approved by the court, but decisions approving settlements are rarely reported. Hence, any analysis based on settlements in published court decisions will both be scant in data and biased toward the more legally controversial cases that get published. There are data on securities class action settlements, but these are limited to a particular type of litigation and, accordingly, do not provide information on other important classes of settlement (such as consumer or mass tort cases). The journal Class A ction Reports contains valuable descriptions of some class actions, including settlements, but coverage is spotty and unsystematic. Case information is maintained by the A dministrative O ffice of the U.S. Courts and by a number of state courts, but cases are not coded according to class action status and therefore are hard to locate.

For lack of a better source of information, we searched The New Y ork Times for class action notices from January 1993 through September $1997 .{ }^{72}$ This generated a sample of 127 cases. We have categorized the notices according to several criteria, including the nature of the court, the case type, and the settlement type. We also have reviewed the attorneys whose names are on the settlement notices, identifying the six most frequently appearing firms. ${ }^{73}$

The results of the empirical study are detailed in the tables below. M ost of the class actions noticed in The N ew Y ork Times are brought in federal court. A s might be expected, the Southern and E astern Districts of N ew Y ork are strongly represented. However, there are cases from a fairly wide variety of other courts, including quite a few state courts. The court breakdown is summarized in the following table: ${ }^{74}$

72. In addition to the New Y ork Times data set, we searched the W estlaw and LEXIS databases for nonpecuniary class action settlements. This search generated a number of additional settlements that provide good examples and information on the dynamics of the settlement process. We have not included the cases generated in the Westlaw and LEXIS searches in the data base drawn from the New Y ork Times because of the differences between the two sources of data.

73. O bviously, the $\mathrm{N}$ ew $\mathrm{Y}$ ork Times data set is subject to challenge as not being particularly representative of the universe of class action cases. It will tend to focus on cases involving $\mathrm{N}$ ew $\mathrm{Y}$ ork defendants or $\mathrm{N} \mathrm{ew} \mathrm{Y}$ ork counsel, and, because of $\mathrm{N}$ ew $\mathrm{Y}$ ork's prominence as a financial center, will tend to include a disproportionate share of securities cases. Nevertheless, because the N ew Y ork Times is a newspaper with national status, it is likely to include a large number of the major, nationwide cases.

74. The percentages in this and the following tables may not add up to 100 due to rounding. 
TABLE A 1

COURT BREAKDOWN

\begin{tabular}{lr}
\hline Southern D istrict of N ew Y ork & $22 \%$ \\
E astern D istrict of N ew Y ork & $6 \%$ \\
O ther F ederal D istricts & $47 \%$ \\
N ew Y ork State C ourt & $10 \%$ \\
Other State Courts & $14 \%$ \\
\hline
\end{tabular}

We divide the cases into the following categories: antitrust, consumer, employment, securities, tort, and other (obviously, judgment calls were required about the nature of some cases). M ost of the class actions were securities cases. Consumer cases are also well represented, many involving claims by mortgagors against the companies that originate, service, or hold their mortgages.

TABLE A 2

CASE BREAKDOWN

\begin{tabular}{lr}
\hline A ntitrust & $3 \%$ \\
Consumer & $30 \%$ \\
Employment & $4 \%$ \\
Securities & $58 \%$ \\
Tort & $4 \%$ \\
Other & $2 \%$ \\
\hline
\end{tabular}

We divide the settlements into seven types: cash, coupon, monitoring, stock, fluid recovery, unknown (that is, the settlement type could not be determined from the class action notice), and other. In categorizing the settlements, we attempt to identify the predominant characteristic. Most settlements have some cash component, but where other types of relief are included, the cash element usually appears to be less significant than the nonpecuniary element, and/or was principally used to compensate the attorneys in cases where the class members received nonpecuniary relief. We could not separately identify whether a particular settlement contained a reverter provision because this information was not contained in the settlement notices. The breakdown does not support the claim sometimes heard in policy circles that coupon settlements have become a major part of the class action landscape. While there are a substantial number of nonpecuniary settlements, including coupons, securities, and monitoring relief, the predominant relief is the cash settlement in which plaintiffs receive real dollars to compensate them for their harm. 
TABLE A 3

SETTLEMENT BREAKDOWN

\begin{tabular}{lr}
\hline Cash & $43 \%$ \\
Coupons & $10 \%$ \\
M onitoring & $2 \%$ \\
Securities & $6 \%$ \\
Fluid R ecovery & $2 \%$ \\
Unknown & $34 \%$ \\
Other & $1 \%$ \\
\hline
\end{tabular}

Finally, we consider the presence of repeat players on the plaintiffs' side, to assess the now-familiar claim that class action litigation is dominated by a few small firms that exercise monopolistic or other form of market dominance. ${ }^{75}$ The six firms whose names appear most frequently on the class notices are $\mathrm{Mil}$ iberg W eiss B ershad $H$ ynes \& L erach; A bbey, G ardy \& Squittier; Zimmerman, Reed PLLP; Bernstein Litowitz Berger \& Grossmann, LLP; B erger \& Montague; and W eiss \& Y ourman. ${ }^{76}$ We determine in how many cases each of these firms appeared (when two or more of the six leading firms appear in the same case, we count the case in each firm's tally). Consistent with expectations, Milberg W eiss is by far the leading firm, followed by a number of firms with about the same share of the cases. It should be noted that these figures probably understate the frequency with which the largest firms are involved in cases, because class action notices published in newspapers frequently omit mention of all the plaintiffs' firms. The following table shows the frequency of each repeat player's appearance as class counsel.

TABLE A 4

CLASS COUNSEL BREAKDOWN (NO. OF CASES)

\begin{tabular}{lr}
\hline M ilberg W eiss & 34 \\
A bbey, G ardner \& Squittier & 9 \\
Z immerman, R eed PL L P & 11 \\
B ernstein Litowitz B erger \& G rossmann, LLP & 8 \\
B erger \& M ontague & 8 \\
Weiss \& Y ourman & 6 \\
\hline
\end{tabular}

75. Milberg Weiss, the reputed leader among plaintiffs' lawyers, was responsible for filing 193 cases between 1988 and mid-1995. See Karen D onovan, Heeeeeeeeeeeeeeeee's Back, FORBES, A ug. 26,1996 , at 78.

76. Somewhat surprisingly, several leading plaintiffs' firms - e.g., Stull, Stull \& Brody and Lieff, Cabraser, H eimann \& B ernstein—were not among the top six firms in the sample. 
The following table provides the complete breakdown of the cases from the N ew Y ork Times data set.

TABLE A 5

NEW YORK TIMESDATA SET

\begin{tabular}{|c|c|c|c|c|c|}
\hline Case name & Date & Court & Case Type & Settlement & A ttorneys \\
\hline $\begin{array}{l}\text { In re A bbey H ealthcare } \\
\text { Securities L itigation }\end{array}$ & $10 / 96$ & C.D. Cal. & Securities & Cash & $\begin{array}{l}\text { M ilberg } \\
\text { Weiss }\end{array}$ \\
\hline $\begin{array}{l}\text { In re A ction Savings } \\
\text { Bank, SLA Securities } \\
\text { Litigation }\end{array}$ & ND & D.N.J. & Securities & Cash & \\
\hline $\begin{array}{l}\text { A kerman v. G reater N ew } \\
\text { Y ork Savings B ank }\end{array}$ & $7 / 93$ & E.D.N.Y. & Securities & Unknown & $\begin{array}{l}\text { W eiss \& } \\
\text { Y ourman }\end{array}$ \\
\hline In re A mbase & ND & S.D.N.Y . & Securities & Unknown & \\
\hline $\begin{array}{l}\text { In re A merican Travelers } \\
\text { Corp. Securities Litiga- } \\
\text { tion }\end{array}$ & ND & E.D.Pa. & Securities & Cash & \\
\hline $\begin{array}{l}\text { In re A mes D epartment } \\
\text { Stores, Inc. D ebenture } \\
\text { Litigation }\end{array}$ & $5 / 93$ & S.D.N.Y . & Securities & Securities & $\begin{array}{l}\text { Milberg } \\
\text { Weiss }\end{array}$ \\
\hline $\begin{array}{l}\text { In re A nn Taylor Stores } \\
\text { Securities L itigation }\end{array}$ & $2 / 93$ & S.D.N.Y . & Securities & Cash & $\begin{array}{l}\text { B ernstein } \\
\text { Litowitz }\end{array}$ \\
\hline $\begin{array}{l}\text { A rnold v. U nlimited } \\
\text { A rtists Theatre Circuit }\end{array}$ & $4 / 96$ & N.D. Cal. & Employment & Other & \\
\hline $\begin{array}{l}\text { Backstrom v. M ethodist } \\
\text { H ospital }\end{array}$ & $7 / 95$ & S.D. Tex. & Consumer & Cash & \\
\hline $\begin{array}{l}\text { Ballan v. E zcony } \\
\text { Interamerica, Inc. }\end{array}$ & $7 / 94$ & S.D. Fla. & Securities & Unknown & \\
\hline $\begin{array}{l}\text { In re Banpais, S.A. } \\
\text { Securities Litigation }\end{array}$ & $10 / 95$ & S.D.N.Y & Securities & Cash & $\begin{array}{l}\text { M ilberg } \\
\text { Weiss }\end{array}$ \\
\hline In re Bausch \& Lomb & $8 / 96$ & N.D. A la. & Consumer & Coupon & \\
\hline $\begin{array}{l}\text { B erlinsky v. A Icatel } \\
\text { A Istholm Compagne } \\
\text { D 'E lectricite }\end{array}$ & $2 / 97$ & S.D.N.Y . & Securities & Cash & $\begin{array}{l}\text { W eiss \& } \\
\text { Y ourman }\end{array}$ \\
\hline $\begin{array}{l}\text { Blatt v. Bertolli U S.A., } \\
\text { Inc. }\end{array}$ & ND & $\begin{array}{l}\text { Cal. Su- } \\
\text { per. Ct. }\end{array}$ & Consumer & Coupon & $\begin{array}{l}\text { Milberg } \\
\text { Weiss }\end{array}$ \\
\hline $\begin{array}{l}\text { In re Ivan F. B oesky } \\
\text { Securities Litigation }\end{array}$ & $6 / 97$ & S.D.N.Y . & Securities & Cash & $\begin{array}{l}\text { B erger \& } \\
\text { Montague }\end{array}$ \\
\hline $\begin{array}{l}\text { B ritt v. G lobal Tel*L ink } \\
\text { Corp. }\end{array}$ & $9 / 95$ & $\begin{array}{l}\text { A la. Cir. } \\
\text { Ct. }\end{array}$ & Consumer & Cash & \\
\hline
\end{tabular}




\begin{tabular}{|c|c|c|c|c|c|}
\hline Case name & Date & Court & Case Type & Settlement & A ttorneys \\
\hline $\begin{array}{l}\text { B urleson v. Independent } \\
\text { O ne M ortgage Corp. }\end{array}$ & $8 / 94$ & $\begin{array}{l}\text { M inn. St. } \\
\mathrm{Ct} .\end{array}$ & Consumer & Cash & \\
\hline $\begin{array}{l}\text { Carter v. The G lobal } \\
\text { Privatization Fund, Inc. }\end{array}$ & ND & S.D.N.Y . & Securities & Unknown & \\
\hline $\begin{array}{l}\text { Capital H oldings, Inc. v. } \\
\text { NY NEX M obile } \\
\text { Communications Co. }\end{array}$ & $4 / 95$ & $\begin{array}{l}\text { N.Y. Sup. } \\
\text { Ct. }\end{array}$ & Consumer & U nknown & $\begin{array}{l}\text { M ilberg } \\
\text { W eiss }\end{array}$ \\
\hline $\begin{array}{l}\text { Charlston-COA D v. } \\
\text { Cunard Line, Ltd. }\end{array}$ & $11 / 95$ & S.D.N.Y . & Consumer & Cash & \\
\hline $\begin{array}{l}\text { In re Cheyenne Software, } \\
\text { Inc. Securities Litigation }\end{array}$ & $7 / 96$ & E.D.N.Y. & Securities & Unknown & $\begin{array}{l}\text { Milberg } \\
\text { W eiss }\end{array}$ \\
\hline $\begin{array}{l}\text { In re Citisource, Inc. } \\
\text { Securities Litigation }\end{array}$ & $1 / 94$ & S.D.N.Y & Securities & Unknown & \\
\hline Cohan v. Loucke, Jr. & $4 / 93$ & Del. Ch. & Securities & Cash & \\
\hline Cohen v. A pache Corp. & $1 / 93$ & S.D.N.Y . & Securities & Cash & \\
\hline $\begin{array}{l}\text { Collins v. Pension Benefit } \\
\text { G uarantee Corp. }\end{array}$ & $4 / 96$ & D.D.C. & E mployment & Cash & \\
\hline $\begin{array}{l}\text { In re Columbia Securities } \\
\text { Litigation }\end{array}$ & ND & S.D.N.Y . & Securities & Cash & \\
\hline $\begin{array}{l}\text { In re Computer } \\
\text { A ssociates, Int'I, Inc. } \\
\text { Securities Litigation }\end{array}$ & $10 / 93$ & E.D.N.Y. & Securities & Unknown & A bbey \\
\hline Computer M onitor Cases & $4 / 97$ & $\begin{array}{l}\text { Cal. Su- } \\
\text { per. Ct. }\end{array}$ & Consumer & Coupon & $\begin{array}{l}\text { Milberg } \\
\text { Weiss }\end{array}$ \\
\hline $\begin{array}{l}\text { In re Coram H ealthcare } \\
\text { Corp. Securities } \\
\text { Litigation }\end{array}$ & $11 / 96$ & D. Colo. & Securities & Securities & $\begin{array}{l}\text { M ilberg } \\
\text { W eiss, } \\
\text { A bbey }\end{array}$ \\
\hline $\begin{array}{l}\text { In re Comptronix } \\
\text { Securities Litigation }\end{array}$ & 9/93 & N.D. A la. & Securities & Cash & $\begin{array}{l}\text { Bernstein } \\
\text { Litowitz }\end{array}$ \\
\hline $\begin{array}{l}\text { In re Cordis Corp. } \\
\text { Pacemaker Product } \\
\text { Liability Litigation }\end{array}$ & $7 / 95$ & S.D. Ohio & Tort & Cash & \\
\hline $\begin{array}{l}\text { In re Corrpro } \\
\text { Companies, Inc. } \\
\text { Securities Litigation }\end{array}$ & $3 / 97$ & N.D.O hio & Securities & Securities & \\
\hline $\begin{array}{l}\text { Cosmopolitan Care Class } \\
\text { A ction Litigation }\end{array}$ & ND & Not Listed & E mployment & Cash & \\
\hline $\begin{array}{l}\text { In re Crazy E ddie } \\
\text { Securities L itigation }\end{array}$ & ND & E.D.N.Y. & Securities & Cash & $\begin{array}{l}\text { M ilberg } \\
\text { W eiss, } \\
\text { A bbey }\end{array}$ \\
\hline
\end{tabular}




\begin{tabular}{|c|c|c|c|c|c|}
\hline Case name & Date & Court & Case Type & Settlement & A ttorneys \\
\hline $\begin{array}{l}\text { In re C\& S Sovran } \\
\text { Shareholder Litigation }\end{array}$ & $4 / 94$ & N.D.Ga. & Securities & Unknown & \\
\hline Curran v. M ascotte & $6 / 96$ & $\begin{array}{l}\text { N.Y. Sup. } \\
\text { Ct. }\end{array}$ & Securities & Unknown & A bbey \\
\hline $\begin{array}{l}\text { In re D ataware } \\
\text { Technologies }\end{array}$ & $8 / 96$ & D. M ass. & Securities & Securities & $\begin{array}{l}\text { Milberg } \\
\text { W eiss }\end{array}$ \\
\hline $\begin{array}{l}\text { In re D omestic A ir } \\
\text { Transportation A ntitrust } \\
\text { Litigation }\end{array}$ & ND & N.D.Ga. & A ntitrust & Coupon & \\
\hline D uncan v. Pencer & $2 / 97$ & S.D.N.Y . & Securities & Cash & $\begin{array}{l}\text { M ilberg } \\
\text { Weiss }\end{array}$ \\
\hline $\begin{array}{l}\text { E hrenreich v. Sensor- } \\
\text { matic E lectronics Corp. }\end{array}$ & $3 / 97$ & S.D. Fla. & Securities & Unknown & $\begin{array}{l}\text { Milberg } \\
\text { Weiss }\end{array}$ \\
\hline In re The Exxon Valdez & $8 / 93$ & $\begin{array}{l}\text { D. A laska. } \\
\& \text { A laska } \\
\text { Super. Ct. }\end{array}$ & Tort & Cash & \\
\hline $\begin{array}{l}\text { F einberg v. D ean W itter } \\
\text { R eynolds }\end{array}$ & $4 / 94$ & $\begin{array}{l}\text { N.Y. Su- } \\
\text { per. Ct. }\end{array}$ & Consumer & Coupon & \\
\hline $\begin{array}{l}\text { Feinberg v. Hibernia } \\
\text { Corp. }\end{array}$ & $12 / 95$ & E.D.La. & Securities & Cash & $\begin{array}{l}\text { W eiss \& } \\
\text { Y ourman }\end{array}$ \\
\hline $\begin{array}{l}\text { Finch v. First Fidelity } \\
\text { Bank }\end{array}$ & $10 / 93$ & $\begin{array}{l}\text { N.J. Super. } \\
\text { Ct. }\end{array}$ & Consumer & Unknown & \\
\hline $\begin{array}{l}\text { First E astern Corp. } \\
\text { v. M ainwaring }\end{array}$ & ND & E.D.Pa. & Securities & Cash & \\
\hline $\begin{array}{l}\text { In re GE E nergy Choice } \\
\text { Lightbulb Consumer } \\
\text { Litigation }\end{array}$ & ND & N.D.Cal. & Consumer & Coupon & $\begin{array}{l}\text { Milberg } \\
\text { W eiss }\end{array}$ \\
\hline $\begin{array}{l}\text { Goshen v. M utual L ife } \\
\text { Insurance } \mathrm{C} \text {. of of N ew } \\
\text { Y ork }\end{array}$ & $12 / 96$ & $\begin{array}{l}\text { N.Y. Sup. } \\
\text { Ct. }\end{array}$ & Consumer & Unknown & $\begin{array}{l}\text { M ilberg } \\
\text { W eiss }\end{array}$ \\
\hline $\begin{array}{l}\text { G redell v. Wyeth } \\
\text { Laboratories, Inc. }\end{array}$ & $11 / 94$ & III. Cir. Ct. & Consumer & Fluid & \\
\hline Gruby v. Brady & $10 / 95$ & S.D.N.Y . & Employment & Unknown & \\
\hline $\begin{array}{l}\text { In re G upta Corp. } \\
\text { Securities Litigation }\end{array}$ & $9 / 95$ & N.D. Cal. & Securities & Unknown & $\begin{array}{l}\text { Milberg } \\
\text { W eiss }\end{array}$ \\
\hline $\begin{array}{l}\text { Guttman v. Clabir Corp. } \\
\text { H ansen v. Suffolk County } \\
\text { NY }\end{array}$ & $\begin{array}{l}6 / 93 \\
11 / 94\end{array}$ & $\begin{array}{l}\text { D. Conn. } \\
\text { E.D.N.Y. }\end{array}$ & $\begin{array}{l}\text { Securities } \\
\text { Other }\end{array}$ & $\begin{array}{l}\text { Cash } \\
\text { Unknown }\end{array}$ & \\
\hline
\end{tabular}




\begin{tabular}{|c|c|c|c|c|c|}
\hline Case name & Date & Court & Case Type & Settlement & A ttorneys \\
\hline $\begin{array}{l}\text { In re H ealth } \\
\text { M anagement Inc. } \\
\text { Securities L itigation }\end{array}$ & $10 / 96$ & E.D.N.Y. & Securities & Cash & \\
\hline $\begin{array}{l}\text { In re H elionetics, Inc. } \\
\text { Securities Litigation }\end{array}$ & $2 / 96$ & C.D. Cal. & Securities & Unknown & $\begin{array}{l}\text { M ilberg } \\
\text { W eiss, } \\
\text { A bbey }\end{array}$ \\
\hline $\begin{array}{l}\text { H errmann v. M eridian } \\
\text { M ortgage Corp. }\end{array}$ & $4 / 97$ & Pa.C.P. & Consumer & Unknown & $\begin{array}{l}\text { Zimmer- } \\
\text { man R eed }\end{array}$ \\
\hline $\begin{array}{l}\text { H irshon v. R epublic of } \\
\text { Bolovia }\end{array}$ & $1 / 97$ & D.D.C. & Securities & Cash & \\
\hline $\begin{array}{l}\text { In re ICN } / V \text { iratek } \\
\text { Securities Litigation }\end{array}$ & $4 / 96$ & S.D.N.Y . & Securities & Unknown & $\begin{array}{l}\text { B ernstein } \\
\text { Litowitz }\end{array}$ \\
\hline $\begin{array}{l}\text { ID S L ife Insurance C o. v. } \\
\text { D arling-D elaware C o., } \\
\text { Inc. }\end{array}$ & $10 / 93$ & N.D. III. & Securities & Securities & \\
\hline $\begin{array}{l}\text { In re In-Store A dvertis- } \\
\text { ing Securities L itigation }\end{array}$ & $10 / 96$ & S.D.N.Y . & Securities & Unknown & $\begin{array}{l}\text { M ilberg } \\
\text { W eiss }\end{array}$ \\
\hline $\begin{array}{l}\text { In re Insurance A ntitrust } \\
\text { Litigation }\end{array}$ & $1 / 95$ & N.D.Cal. & A ntitrust & Fluid & $\begin{array}{l}\text { B erger \& } \\
\text { M ontague }\end{array}$ \\
\hline $\begin{array}{l}\text { In re Integrated } \\
\text { R esources Securities } \\
\text { Litigation }\end{array}$ & $4 / 95$ & S.D.N.Y & Securities & Cash & \\
\hline $\begin{array}{l}\text { Intel } 486 \text { Processor } \\
\text { Litigation }\end{array}$ & $11 / 96$ & Pa. C.P. & Consumer & Coupon & \\
\hline Israel v. Citibank, N.A. & $2 / 93$ & $\begin{array}{l}\text { Mo. Cir. } \\
\text { Ct. }\end{array}$ & Consumer & Unknown & \\
\hline $\begin{array}{l}\text { J acobson v. Midland } \\
\text { M ortgage Co. }\end{array}$ & $2 / 94$ & D. Minn. & Consumer & Unknown & $\begin{array}{l}\text { Zimmer- } \\
\text { man R eed }\end{array}$ \\
\hline $\begin{array}{l}\text { J/H R eal E state, Inc. v. } \\
\text { A bramson }\end{array}$ & $11 / 96$ & E.D.Pa. & Securities & Cash & $\begin{array}{l}\text { M ilberg } \\
\text { W eiss, } \\
\text { B erger \& } \\
\text { M ontague }\end{array}$ \\
\hline $\begin{array}{l}\text { J ohnston v. Comerica } \\
\text { M ortgage Corp. }\end{array}$ & $8 / 94$ & D. Minn. & Consumer & Cash & $\begin{array}{l}\text { Zimmer- } \\
\text { man R eed }\end{array}$ \\
\hline $\begin{array}{l}\text { In re J oint E astern and } \\
\text { Southern D istrict A sbes- } \\
\text { tos Litigation }\end{array}$ & $8 / 94$ & $\begin{array}{l}\text { E.D.N.Y. } \\
\& \\
\text { S.D.N.Y. }\end{array}$ & Tort & Unknown & \\
\hline $\begin{array}{l}\text { Kaplan v. E F H utton } \\
\text { G roup, Inc. }\end{array}$ & $12 / 93$ & $\begin{array}{l}\text { N.Y. Sup. } \\
\text { Ct. }\end{array}$ & Securities & Cash & \\
\hline $\begin{array}{l}\text { K ruse v. Barclays A meri- } \\
\text { can M ortgage Corp. }\end{array}$ & $6 / 94$ & D. M inn. & Consumer & Cash & $\begin{array}{l}\text { Zimmer- } \\
\text { man R eed }\end{array}$ \\
\hline
\end{tabular}




\begin{tabular}{|c|c|c|c|c|c|}
\hline Case name & Date & Court & Case Type & Settlement & A ttorneys \\
\hline $\begin{array}{l}\text { Lard v. L eucadia } \\
\text { National Corp. }\end{array}$ & $5 / 95$ & $\begin{array}{l}\text { N.Y. Sup. } \\
\text { Ct. }\end{array}$ & Securities & Unknown & $\begin{array}{l}\text { M ilberg } \\
\text { W eiss }\end{array}$ \\
\hline $\begin{array}{l}\text { Leo v. G eneral E lectric } \\
\text { Co. }\end{array}$ & $8 / 93$ & $\begin{array}{l}\text { N.Y. Sup. } \\
\text { Ct. }\end{array}$ & Other & Unknown & \\
\hline $\begin{array}{l}\text { Lerner v. Statewide } \\
\text { Bancorp }\end{array}$ & ND & D.N.J. & Securities & Cash & \\
\hline LTV Steel Co. & $2 / 95$ & Not L isted & Securities & Cash & \\
\hline $\begin{array}{l}\text { M ark v. K ey Corp. } \\
\text { M ortgage, Inc. }\end{array}$ & $6 / 97$ & N.D. III. & Consumer & Cash & $\begin{array}{l}\text { Zimmer- } \\
\text { man R eed }\end{array}$ \\
\hline $\begin{array}{l}\text { M arton and } M \text { arton v. } \\
\text { M etmor Financial, Inc. }\end{array}$ & $4 / 97$ & $\begin{array}{l}\text { Nev. D ist. } \\
\text { Ct. }\end{array}$ & Securities & Unknown & \\
\hline $\begin{array}{l}\text { In re M elridge, Inc. } \\
\text { Securities Litigation }\end{array}$ & $9 / 93$ & D. Or. & Securities & Cash & $\begin{array}{l}\text { B erger \& } \\
\text { M ontague }\end{array}$ \\
\hline $\begin{array}{l}\text { M eserow v. Sears } \\
\text { M ortgage Corp. }\end{array}$ & $7 / 94$ & D. M inn. & Consumer & Cash & $\begin{array}{l}\text { Zimmer- } \\
\text { man R eed }\end{array}$ \\
\hline $\begin{array}{l}\text { In re M ichael M ilkin and } \\
\text { A ssociates Securities } \\
\text { Litigation }\end{array}$ & ND & S.D.N.Y. & Securities & Unknown & $\begin{array}{l}\text { Berger \& } \\
\text { M ontague }\end{array}$ \\
\hline $\begin{array}{l}\text { M ichels v. Phoenix H ome } \\
\text { Life M utual I nsurance } \\
\text { Co. }\end{array}$ & 9/96 & $\begin{array}{l}\text { N.Y. Sup. } \\
\text { Ct. }\end{array}$ & Consumer & Coupon & \\
\hline $\begin{array}{l}\text { M orton v. B ancPL U S } \\
\text { M ortgage Corp. }\end{array}$ & $11 / 95$ & N.D.III. & Consumer & Unknown & $\begin{array}{l}\text { Zimmer- } \\
\text { man R eed }\end{array}$ \\
\hline $\begin{array}{l}\text { M ufford v. D ale } \\
\text { M ortgage B ankers Corp. }\end{array}$ & $2 / 96$ & $\begin{array}{l}\text { N.Y. Sup. } \\
\text { Ct. }\end{array}$ & Consumer & U nknown & $\begin{array}{l}\text { Zimmer- } \\
\text { man R eed }\end{array}$ \\
\hline $\begin{array}{l}\text { Natal v. Transamerica } \\
\text { O ccidental L ife } \\
\text { Insurance C } 0 .\end{array}$ & $4 / 97$ & $\begin{array}{l}\text { Cal. Su- } \\
\text { per. Ct. }\end{array}$ & Consumer & Coupon & \\
\hline $\begin{array}{l}\text { In re N et W orth Inc. } \\
\text { Securities L itigation }\end{array}$ & $10 / 94$ & N.D. Tex & Securities & Cash & $\begin{array}{l}\text { Bernstein } \\
\text { Litowitz, } \\
\text { M ilberg } \\
\text { W eiss }\end{array}$ \\
\hline $\begin{array}{l}\text { In re N orand Corp. } \\
\text { Securities L itigation }\end{array}$ & $11 / 96$ & N.D. I owa & Securities & Securities & $\begin{array}{l}\text { B ernstein } \\
\text { Litowitz, } \\
\text { M ilberg } \\
\text { W eiss }\end{array}$ \\
\hline $\begin{array}{l}\text { In re O racle Securities } \\
\text { Litigation }\end{array}$ & ND & N.D.Cal. & Securities & Cash & \\
\hline
\end{tabular}




\begin{tabular}{|c|c|c|c|c|c|}
\hline Case name & Date & Court & Case Type & Settlement & A ttorneys \\
\hline $\begin{array}{l}\text { In re Packard Bell } \\
\text { Consumer Class A ction } \\
\text { Litigation }\end{array}$ & $7 / 95$ & $\begin{array}{l}\text { Cal. Su- } \\
\text { per. Ct. }\end{array}$ & Consumer & Monitoring & $\begin{array}{l}\text { M ilberg } \\
\text { W eiss, } \\
\text { B ernstein } \\
\text { Litowitz }\end{array}$ \\
\hline $\begin{array}{l}\text { In re Paine W ebber } \\
\text { Limited Partnerships } \\
\text { Litigation }\end{array}$ & $8 / 96$ & S.D.N.Y . & Securities & Cash & $\begin{array}{l}\text { M ilberg } \\
\text { W eiss }\end{array}$ \\
\hline $\begin{array}{l}\text { In re Pentium Processor } \\
\text { Litigation }\end{array}$ & $4 / 95$ & $\begin{array}{l}\text { Cal. Su- } \\
\text { per. Ct. }\end{array}$ & Consumer & Monitoring & $\begin{array}{l}\text { M ilberg } \\
\text { W eiss, } \\
\text { B ernstein } \\
\text { Litowitz, } \\
\text { W eiss \& } \\
\text { Y ourman }\end{array}$ \\
\hline $\begin{array}{l}\text { Prince G eorge Center, } \\
\text { Inc. v. U .S. G ypsum Co. }\end{array}$ & $3 / 95$ & Pa. C.P. & Tort & Cash & \\
\hline $\begin{array}{l}\text { In re The Prudential Ins. } \\
\text { Company of A merica } \\
\text { Sales Practices L itigation }\end{array}$ & $10 / 96$ & D.N.J . & Consumer & Coupon & \\
\hline $\begin{array}{l}\text { In re Prudential } \\
\text { Securities Inc. Limited } \\
\text { Partnerships L itigation }\end{array}$ & 9/95 & S.D.N.Y . & Securities & Cash & $\begin{array}{l}\text { M ilberg } \\
\text { W eiss }\end{array}$ \\
\hline $\begin{array}{l}\text { Pruitt v. R ockefeller } \\
\text { Center Properties, Inc. }\end{array}$ & $3 / 93$ & $\begin{array}{l}\text { N.Y. Sup. } \\
\text { Ct. }\end{array}$ & Securities & Securities & \\
\hline Pryor v. U SX Corp. & $3 / 93$ & S.D.N.Y . & Securities & Cash & \\
\hline $\begin{array}{l}\text { Reebok International, } \\
\text { Inc. A ntitrust Litigation }\end{array}$ & $7 / 95$ & S.D.N.Y & A ntitrust & Fluid & \\
\hline $\begin{array}{l}\text { R oberts v. U.S. } \\
\text { H omecare Corp. }\end{array}$ & $11 / 94$ & S.D.N.Y. & Securities & Cash & \\
\hline $\begin{array}{l}\text { In re Sahlen and } \\
\text { A ssociates, Inc. Securities } \\
\text { Litigation }\end{array}$ & $5 / 94$ & S.D. Fla. & Securities & Unknown & \\
\hline Scheatzle v. E ubanks & $5 / 94$ & N.D.Cal. & Securities & Cash & $\begin{array}{l}\text { Milberg } \\
\text { W eiss }\end{array}$ \\
\hline Rose v. Cooney & $7 / 94$ & D. Conn. & Employment & Cash & $\begin{array}{l}\text { Berger \& } \\
\text { M ontague }\end{array}$ \\
\hline $\begin{array}{l}\text { R osenbaum v. } \\
\text { M acA lister }\end{array}$ & $10 / 93$ & D. Colo. & Securities & Unknown & \\
\hline $\begin{array}{l}\text { Schneider v. GE Capital } \\
\text { M ortgage Services, Inc. }\end{array}$ & $2 / 97$ & S.D.N.Y . & Consumer & Cash & \\
\hline $\begin{array}{l}\text { Schwab v. A merica } \\
\text { On-Line, Inc. }\end{array}$ & $5 / 96$ & III. Cir. Ct. & Consumer & Coupon & $\begin{array}{l}\text { M ilberg } \\
\text { W eiss }\end{array}$ \\
\hline
\end{tabular}




\begin{tabular}{|c|c|c|c|c|c|}
\hline Case name & Date & Court & Case Type & Settlement & A ttorneys \\
\hline $\begin{array}{l}\text { Searcy v. Victoria } \\
\text { M ortgage Corp. }\end{array}$ & $1 / 96$ & N.D.III. & Consumer & Unknown & $\begin{array}{l}\text { Zimmer- } \\
\text { man Reed }\end{array}$ \\
\hline $\begin{array}{l}\text { Shea v. N ew Y ork Life } \\
\text { Insurance C } 0 \text {. }\end{array}$ & $5 / 96$ & S.D. Fla. & Securities & Unknown & \\
\hline Siegel v. Syncronys & $3 / 96$ & III. Cir. Ct. & Consumer & Coupon & \\
\hline $\begin{array}{l}\text { Silverman v. CPS } \\
\text { Chemical Co. }\end{array}$ & $1 / 94$ & D.N.J. & Securities & Unknown & \\
\hline $\begin{array}{l}\text { In re SLM International, } \\
\text { Inc. Securities L itigation }\end{array}$ & ND & S.D.N.Y & Securities & Securities & $\begin{array}{l}\text { M ilberg } \\
\text { W eiss, } \\
\text { A bbey }\end{array}$ \\
\hline $\begin{array}{l}\text { Smith v. Torchmark } \\
\text { Corp. }\end{array}$ & $3 / 96$ & W.D.Mo. & A ntitrust & Unknown & \\
\hline $\begin{array}{l}\text { In re Snapple B everage } \\
\text { Corp. Securities } \\
\text { Litigation }\end{array}$ & $1 / 97$ & E.D.N.Y. & Securities & Cash & A bbey \\
\hline $\begin{array}{l}\text { Soicher v. L ong I sland } \\
\text { Savings B ank }\end{array}$ & $5 / 95$ & $\begin{array}{l}\text { N.Y. Sup. } \\
\text { Ct. }\end{array}$ & Consumer & Unknown & $\begin{array}{l}\text { M ilberg } \\
\text { W eiss }\end{array}$ \\
\hline $\begin{array}{l}\text { In re Soybean Futures } \\
\text { Litigation }\end{array}$ & $10 / 96$ & N.D.III. & Securities & Unknown & \\
\hline $\begin{array}{l}\text { Spillane v. G.T. G reater } \\
\text { E urope F und }\end{array}$ & $9 / 96$ & N.D. Cal. & Securities & Unknown & $\begin{array}{l}\text { M ilberg } \\
\text { W eiss, } \\
\text { W eiss \& } \\
\text { Y ourman }\end{array}$ \\
\hline $\begin{array}{l}\text { Spitz v. Connecticut } \\
\text { G eneral Life Insurance } \\
\text { Co. }\end{array}$ & $10 / 96$ & C.D. Cal. & Consumer & Unknown & \\
\hline Stark v. Dievler & ND & $\begin{array}{l}\text { N.Y. Sup. } \\
\text { Ct. }\end{array}$ & Securities & Unknown & A bbey \\
\hline $\begin{array}{l}\text { In re Storage Technology } \\
\text { Securities Litigation }\end{array}$ & $3 / 95$ & D. Colo. & Securities & Unknown & $\begin{array}{l}\text { B erger \& } \\
\text { M ontague, } \\
\text { B ernstein } \\
\text { L itowitz }\end{array}$ \\
\hline $\begin{array}{l}\text { In re Sun H ealthcare } \\
\text { G roup, Inc. Litigation }\end{array}$ & 2/97 & D.N.M. & Securities & Cash & A bbey \\
\hline $\begin{array}{l}\text { In re Taxable M unicipal } \\
\text { Bond Securities } \\
\text { Litigation }\end{array}$ & $2 / 95$ & E.D.La. & Securities & Cash & \\
\hline $\begin{array}{l}\text { In re Tiphook Securities } \\
\text { Litigation }\end{array}$ & $4 / 95$ & D.N.J . & Securities & Cash & $\begin{array}{l}\text { B erger \& } \\
\text { M ontague }\end{array}$ \\
\hline $\begin{array}{l}\text { Trief v. D un \& } \\
\text { B radstreet Corp. }\end{array}$ & $7 / 93$ & S.D.N.Y & Securities & Unknown & \\
\hline
\end{tabular}




\begin{tabular}{|c|c|c|c|c|c|}
\hline Case name & Date & Court & Case Type & Settlement & A ttorneys \\
\hline U rbach v. Sayles & 2/95 & D.N.J. & Securities & Cash & \\
\hline $\begin{array}{l}\text { Wills v. Cenlar F ederal } \\
\text { Savings Bank }\end{array}$ & $8 / 94$ & D. Minn. & Consumer & Cash & $\begin{array}{l}\text { Zimmer- } \\
\text { man R eed }\end{array}$ \\
\hline $\begin{array}{l}\text { Willson v. New Y ork Life } \\
\text { Insurance Co. }\end{array}$ & $10 / 96$ & $\begin{array}{l}\text { N.Y. Sup. } \\
\text { Ct. }\end{array}$ & Consumer & Coupon & $\begin{array}{l}\text { Milberg } \\
\text { W eiss }\end{array}$ \\
\hline $\begin{array}{l}\text { Wingate } v \text {. B ank of } \\
\text { A merica }\end{array}$ & $3 / 95$ & C.D. Cal. & Consumer & Cash & $\begin{array}{l}\text { Zimmer- } \\
\text { man R eed }\end{array}$ \\
\hline $\begin{array}{l}\text { Woodward v. Nor-A m } \\
\text { Chemical Co. }\end{array}$ & $9 / 95$ & S.D. A la. & Tort & Monitoring & \\
\hline $\begin{array}{l}\text { Zicklin v. Phillips-Van } \\
\text { Heusen Corp. }\end{array}$ & $4 / 97$ & S.D.N.Y . & Securities & Cash & $\begin{array}{l}\text { M ilberg } \\
\text { W eiss }\end{array}$ \\
\hline Zucker v. Sasaki & $5 / 97$ & S.D.N.Y & Securities & Unknown & $\begin{array}{l}\text { M ilberg } \\
\text { W eiss, } \\
\text { W eiss \& } \\
\text { Y ourman }\end{array}$ \\
\hline $\begin{array}{l}\text { In re ZZZZ B est Securi- } \\
\text { ties Litigation }\end{array}$ & $10 / 95$ & C.D.Cal. & Securities & Unknown & \\
\hline
\end{tabular}

Notes: The "A bbey" firm refers to the firm formerly known as Abbey \& Ellis and now Abbey G ardy \& Squitieri; the Weiss \& Y ourman firm was formerly J oseph Weiss, E sq. "ND " means "no date."

\section{B. A ttorneys' Fees in Common Fund Cases}

In this section, we examine the rules on common fund and common benefit fee awards in the federal circuits and in each of the fifty states. ${ }^{77} \mathrm{~A}$ detailed analysis of the results of this survey is contained in Table 9 (federal courts of appeals) and Table 10 (state courts). We briefly summarize the results here.

We divide fee rules into five general categories: lodestar, percentage, percentage or lodestar, multifactor, and unsettled. There is some degree of judgment required for this categorization, since the decisions are not always perfectly clear and since they sometimes endorse one approach while approving fees apparently set through some other method. M oreover, there may be variation in the actual operation of particular methodologies in setting fees that have significant impacts on actual fees. For example, two states may use the lodestar

77. For background on attorneys' fees in class actions, see B ruce $\mathrm{H}$ ay, The Theory of Fee Regulation in Class A ction Settlements, 46 A M E R. U . L. REV. 1429 (1997); M onique Lapointe, N ote, A ttorneys Fees in Common Fund Actions, 59 FORDHAM L. REV. 843 (1991); J onathan R. M acey \& G eoffrey P. M iller, The Plaintiffs' A ttorney's Role in Class Action and Derivative Litigation: E conomic A nalysis and Recommendations for Reform, 58 U. CHI. L. REV. 1 (1991); Charles Silver, Incoherence \& Irrationality in the Law of Attorneys' Fees, 12 REV. LITIG. 301 (1993); Charles Silver, A Restitutionary Theory of A ttorneys' Fees in Class A ctions, 76 COR NE LL L. REV. 656 (1991); Charles Silver, U nloading the L odestar: T oward a N ew F ee A ward Procedure, 70 TEX. L. REV. 865 (1992). 
approach, but one may allow contingency enhancements and the other not; the end result will be significant variation in the fees awarded.

In the federal courts, the cases reveal a distinct trend away from the lodestar approach and toward the percentage approach. Three federal circuits now appear to mandate the use of the percentage approach, and only two - the Second and Fifth Circuits - use the lodestar without permitting the percentage approach at least as an alternative mechanism. The other circuits (other than the Federal Circuit, which has no rule) give trial courts wide discretion in setting fees, but permit (and sometimes encourage) the use of the percentage approach. The federal circuits break down as follows:

TABLE A 6

FEDERAL CIRCUIT BREAKDOWN

\begin{tabular}{ll}
\hline Lodestar & 2 \\
Percentage & 3 \\
E ither & 6 \\
Factor A nalysis & 1 \\
U nsettled & 1 \\
\hline
\end{tabular}

In the states, we see a significantly different picture. ${ }^{78}$ Some states have joined the federal trend toward the percentage method; for example, A labama adopted the percentage of the recovery method in 1995, and Illinois permitted but did not require the percentage approach the same year. However, other states have gone in the opposite direction. Florida rejected the percentage approach in 1995, and California appeared to require the lodestar approach and to disapprove percentage fees in 1991. Indeed, there are a few states in which common benefit recoveries are not recognized, and at least one - V ermont - that has yet to accept even the common fund rule on class action fees. A summary breakdown of state fee rules is shown in the following table:

78. To the best of our knowledge, there is no previous state-by-state survey of fee award methods in class action cases. 
TABLE A 7

STATE BREAKDOWN

\begin{tabular}{lc}
\hline Lodestar & 7 \\
Percentage & 3 \\
Either & 8 \\
Factor A nalysis & 15 \\
Unsettled & 17 \\
\hline
\end{tabular}

To what extent do we observe nonpecuniary settlements being brought into courts that have discretion to award fees on a percentage method? 0 ur data do not support the proposition that the applicable rule on attorneys' fees influences the choice between nonpecuniary and cash settlements. However, the small sample size makes it impossible to draw firm conclusions. M oreover, because the newspaper we use for our data (the $\mathrm{N} \mathrm{ew} \mathrm{Y} \mathrm{ork} \mathrm{Times)} \mathrm{is} \mathrm{based} \mathrm{in} \mathrm{N} \mathrm{ew}$ $\mathrm{Y}$ ork, the cases reflect a fairly high percentage of $\mathrm{N}$ ew $\mathrm{Y}$ ork litigation, and neither the state nor the federal courts in N ew $\mathrm{Y}$ ork permit percentage of the recovery fees. Of our sample of settlements in the N ew Y ork Times data set, we find the following:

TABLE A 8

A TTORNEYSFEESRULESIN NONPECUNIARY CASES

\begin{tabular}{lcccc}
\hline Type of Settlement & Total & $\begin{array}{c}\text { Percentage } \\
\text { Required }\end{array}$ & $\begin{array}{c}\text { Percentage } \\
\text { Permitted }\end{array}$ & $\begin{array}{c}\text { Percentage N ot } \\
\text { Permitted }\end{array}$ \\
\hline Coupon & 13 & 3 & 4 & 6 \\
Securities & 9 & 1 & 5 & 3 \\
Fluid R ecovery & 3 & 0 & 2 & 1 \\
M onitoring & 3 & 1 & 0 & 2 \\
\hline
\end{tabular}

More complete information on applicable attorneys' fee rules in federal and state courts is provided in the following tables. 
TA BLE A 9

COMMON Fund or COMMON BEnEFIT A WARDSOF A TTORnEys' FEes in CLASSACTIONS: FEDERAL RULES

\begin{tabular}{|c|c|c|}
\hline Circuit & M ethod & Notes \\
\hline First & L odestar or Percentage $^{79}$ & $\begin{array}{l}\text { Court expresses preference for percent- } \\
\text { age method }{ }^{80}\end{array}$ \\
\hline Second & Lodestar $^{81}$ & \\
\hline Third & Percentage ${ }^{82}$ & $\begin{array}{l}\text { L odestar can be used as check on per- } \\
\text { centage } \text { award }^{83}\end{array}$ \\
\hline Fourth & Multi-factor ${ }^{84}$ & \\
\hline Fifth & L odestar $^{85}$ & \\
\hline Sixth & L odestar or Percentage $^{86}$ & \\
\hline Seventh & 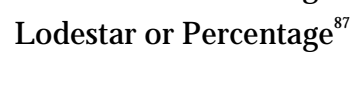 & $\begin{array}{l}\text { Court expresses preference for percent- } \\
\text { age method }{ }^{88}\end{array}$ \\
\hline Eighth & L odestar or Percentage $^{89}$ & \\
\hline Ninth & L odestar or Percentage $^{90}$ & $\begin{array}{l}\text { "B enchmark" of } 25 \text { percent of common } \\
\text { fund recognized. }{ }^{91}\end{array}$ \\
\hline Tenth & L odestar or Percentage $^{92}$ & $\begin{array}{l}\text { Court expresses preference for percent- } \\
\text { age method; }{ }^{93} \text { but percentage is not used } \\
\text { common benefit cases. }{ }^{94}\end{array}$ \\
\hline Eleventh $^{95}$ & Percentage & \\
\hline
\end{tabular}

79. See In re Thirteen A ppeals A rising out of the San J uan D uPont Plaza H otel Fire Litig., 56 F.3d 295, 306-08 (1st Cir. 1995).

80. See W einberger v. G reat N. N ekoosa Corp., 925 F.2d 518, 526 n.10 (1st Cir. 1991).

81. See In re A gent O range Prods. Liab. Litig., 818 F.2d 226, 232 ( 2 d Cir.), cert. denied, 484 U .S. 926 (1987).

82. See In re General M otors Corp. Pick-U p Truck Fuel Tank Prods. L iab. Litig., 55 F.3d 768, 821 (3d Cir.), cert. denied, 516 U.S. 824 (1995). 1995).

83. See, e.g., Strang v. J H M M ortgage Sec. Ltd. Partnership, 890 F. Supp. 499, 502-03 (E.D. Va.

84. See A llen v. U nited States, 606 F.2d 432 (4th Cir. 1979) (not a class action).

85. See Forbush v. J.C. Penney C 0., 98 F.3d 817, 821 (5th Cir. 1996); J ohnson v. G eorgia Highway Express I nc., 488 F.2d 714, 716-17 (5th Cir. 1974).

86. See R awlings v. Prudential-B ache Props., Inc., 9 F.3d 513, 516 (6th Cir. 1993).

87. See Florin v. Nationsbank of G a., 34 F.3d 560 (7th Cir. 1994).

88. See In re Continental III. Sec. Litig., 962 F.2d 566, 572-73 (7th Cir. 1992).

89. See J ohnston v. Cenlar Fed. Sav. Bank, 83 F.3d 241 (8th Cir. 1996).

90. See In re W ash. Pub. Power Supply Sys. Sec. Litig., 19 F.3d 1291, 1295 (9th Cir. 1994).

91. See Six M exican Workers v. A rizona Citrus G rowers, 904 F.2d 1301, 1311 (9th Cir. 1990). (1988).

92. See Brown v. Phillips Petroleum Co., 838 F.2d 451, 454 (10th Cir.), cert. denied, 488 U .S. 822

93. See R osenbaum v. M acCallister, 64 F.3d 1439, 1445 (10th Cir. 1995).

94. See id.

95. See Camden I Condo. A ss'n v. D unkle, 946 F.2d 768 (11th Cir. 1991). 


\begin{tabular}{lll}
\hline \multicolumn{1}{c}{ Circuit } & M ethod & Notes \\
\hline District of & Percentage $^{96}$ & \\
Columbia & & \\
Federal & Unsettled & \\
\hline
\end{tabular}

TABLE A 10

COMmOn Fund or COMmon Benefit A WARds of A tTorneys' FeES in CLASS A CTIONS: StATE RULES

\begin{tabular}{|c|c|c|}
\hline State & M ethod & Notes \\
\hline A labama & Percentage $^{97}$ & $\begin{array}{l}\text { Percentage adopted for common fund class } \\
\text { actions in } 1995 ;^{98} \text { multi-factor test used } \\
\text { earlier }{ }^{99}\end{array}$ \\
\hline A laska & $\begin{array}{l}\text { L odestar or } \\
\text { Percentage }{ }^{100}\end{array}$ & $\begin{array}{l}\text { M odified E nglish R ule under which losing } \\
\text { party pays winner's fees in certain cases. }{ }^{101} \\
\text { Courts assessing fees first determine } \\
\text { "compensable value" of attorney's services } \\
\text { to class and then apply fee-shifting rule. }{ }^{102} \\
\text { H owever, difficulty in calculating value of } \\
\text { common benefit may make percentage } \\
\text { approach inappropriate. }{ }^{103}\end{array}$ \\
\hline
\end{tabular}

\footnotetext{
96. See Swedish H osp. Corp. v. Shalala, 1 F.3d 1261 (D.C. Cir. 1993).

97. See E delman \& Combs v. Law, 663 So. $2 d 957$ (A la. 1995).

98. See id.

99. See State v. Brown, 577 So. $2 d 1256$ (A la. 1991). The factors are the following:
}

(1) [t]he measure of success achieved, (2) [t]he nature and value of the subject matter of the attorney's employment, including the novelty and difficulty of the questions presented; (3) [t]he learning, skill, and labor requisite to perform the legal service properly; (4) [t]he time consumed and reasonable expenses incurred by the attorney; (5) [t]he professional experience, reputation and ability of the attorney; (6) [t]he weight of his responsibility; (7) [t]he fee arrangement between attorney and client, including whether a fee was fixed or contingent; (8) [t]he fee customarily charged in the locality for similar legal services and awards in similar cases; (9) [t]he time limitations imposed by the client or by the circumstances; (10) [t]he likelihood that the attorney's employment in this case precluded other employment; (11) [t]he nature and length of the professional relationship with the client; (12) [t]he undesirability of Id. at 1258 .

the case; (13) [a]ny non-monetary benefits conferred upon the class.

100. See E dwards v. A laska Pulp Corp., 920 P.2d 751 (A laska 1996). Fees may also be awarded to counsel for the prevailing class against the defendant under A laska's English R ule on fee-shifting. See M unicipality of A nchorage v. G allion, 944 P.2d 436 (A laska 1997); M unicipality of A nchorage v. G entile, 922 P.2d 248, 266 (A laska 1996). A s described more fully below, either lodestar or percentage may be used in calculating the fee-shifting award, although, depending on how the rule is applied, class counsel may not receive full recovery when fees are awarded against the defendant.

101. SeeA LASKA R. CIV. P. 82(a).

102. M unicipality of A nchorage v. Gentile, 922 P.2d 248, 263 (A laska 1996) (Trial courts in class action cases should " $(1)$ determine the compensable value of the services the attorneys rendered to the 


\begin{tabular}{|c|c|c|}
\hline State & M ethod & Notes \\
\hline A rizona & $\begin{array}{l}\text { L odestar }{ }^{104} \text { or } \\
\text { Percentage }\end{array}$ & $\begin{array}{l}\text { Percentage fee may be limited to private } \\
\text { attorney general actions }\end{array}$ \\
\hline A rkansas & M ulti-factor ${ }^{106}$ & $\begin{array}{l}\text { Percentage may be one factor to be } \\
\text { considered }^{107}\end{array}$ \\
\hline California & Lodestar ${ }^{108}$ & $\begin{array}{l}\text { Percentage method of "questionable } \\
\text { validity." } \\
\text { applies only when litigation generates } \\
\text { "certain or easily calculable sum of } \\
\text { money." }{ }^{110} \mathrm{~N} \text { o recovery under percentage } \\
\text { method for coupon settlements. } \\
\text { Contingency risk enhancement permitted in } \\
\text { lodestar cases. }\end{array}$ \\
\hline Colorado & M ulti-factor ${ }^{113}$ & $\begin{array}{l}\text { Common fund doctrine. }{ }^{114} \mathrm{~A} \text { ttorneys' fees in } \\
\text { class actions against public entities limited } \\
\text { by statute. } .^{115}\end{array}$ \\
\hline
\end{tabular}

class, and (2) apply R ule 82 to the amount calculated in Step 1 to decide how much [the non-prevailing party] should pay."). In determining the compensable value of class counsel's services, the court may consider such factors as "the need to promote the efficient use of court resources" through the use of class action litigation, and "the potential difficulty of attracting capable counsel." Id. at 264. The absence of a traditional fund does not preclude application of the common fund rationale in an appropriate case, when evaluating the attorney's services during Step 1. Id. at 266. Because A laska's R ule 82 is designed to provide only partial, not full compensation to prevailing parties, strict application of the rule would result in class action attorneys receiving less than market value compensation. H owever, the A laska Supreme Court has suggested that the trial court may, in its discretion, adjust the award upward to a fully compensatory fee if the standards of R ule 82(b)(3) warrant doing so. See M unicipality of A nchorage v. Gallion, 944 P.2d 436 (A laska 1997).

103. See id.

104. See L ondon v. G reen A cres Trust, 765 P.2d 538 (A riz. Ct. A pp. 1988).

105. The A rizona Supreme Court awarded a percentage fee in a "private attorney general" action designed to vindicate important public policies. See A rnold v. A riz. D ep't of Health Servs., 775 P.2d 521 (A riz. 1989).

106. See Powell v. Henry, 592 S.W. 2 d 107, 109 (A rk. 1980) (time spent on case is only one factor to be considered; other factors include the ability of counsel, the nature and extent of the services rendered, the result obtained, the percentage of the recovery, and uncertainty of ultimate recovery).

107. See id. at 111 (approving an award of $15 \%$ of the recovery under a factor analysis, but declining to set specific percentage standards).

108. See, e.g., Rebney v. W ells Fargo B ank, 284 Cal. R ptr. 113 (Cal. Ct. A pp. 1991); Serrano v. Priest, 569 P.2d 1303 (Cal. 1977).

109. See D unk v. Ford M otor Co., 56 Cal. R ptr. 2d 483, 493 (Cal. Ct. A pp. 1996); see also People ex rel. D ep't of Transp. v. Y uki, 37 Cal. R ptr. 2d 616 (Cal. Ct. A pp. 1995); Serrano v. Priest, 569 P.2d 1303 (Cal. 1977) (acknowledging possibility of percentage method in California, but not deciding the issue).

110. Serrano, 569 P.2d at 1307.

111. See D unk v. Ford M otor C 0., 56 Cal. R ptr. 2d 483 (Cal. Ct. A pp. 1996).

112. See B easley v. W ells Fargo B ank, 1 Cal. R ptr. 2d 459 (Cal. Ct. A pp. 1991).

113. See City of Wheat R idge v. Cerveny, 913 P.2d 1110 (Colo. 1996) (not a class action) (adopting standards of DR 2-106); M au v. E.P.H. Corp., 638 P.2d 777 (Colo. 1981). In K uhn v. State, 924 P.2d 1053 (Colo. 1996), the trial court approved an attorneys' fee based on $25 \%$ of a common fund, but the Supreme Court of Colorado did not address the issue whether the percentage method is a generally accepted means for determining fees in common fund cases. 


\begin{tabular}{|c|c|c|}
\hline State & M ethod & Notes \\
\hline Connecticut & M ulti-factor ${ }^{116}$ & \\
\hline Delaware & M ulti-factor ${ }^{117}$ & $\begin{array}{l}\text { Common fund doctrine. }{ }^{118} \text { R ecent Supreme } \\
\text { Court decision affirmed award of one-third } \\
\text { of amounts actually paid in a reverter } \\
\text { settlement but denying recovery for } \\
\text { unclaimed amounts. }{ }^{119}\end{array}$ \\
\hline Florida & L odestar ${ }^{120}$ & Common fund doctrine $e^{121}$ \\
\hline G eorgia & U nsettled & $\begin{array}{l}\text { Common fund and common benefit } \\
\text { recovery }\end{array}$ \\
\hline H awaii & L odestar $^{123}$ & Common fund recoveries ${ }^{124}$ \\
\hline Idaho & Unsettled & \\
\hline Illinois & $\begin{array}{l}\text { Lodestar or } \\
\text { Percentage }^{125}\end{array}$ & $\begin{array}{l}1995 \text { decision revised previous rule requiring } \\
\text { use of lodestar }\end{array}$ \\
\hline Indiana & $\begin{array}{l}\text { L odestar or } \\
\text { Percentage }^{127}\end{array}$ & $\begin{array}{l}1996 \text { decision declined to follow federal } \\
\text { trend mandating percentage method }\end{array}$ \\
\hline lowa & M ulti-factor ${ }^{128}$ & $\begin{array}{l}\text { Factor analysis may result in approval of } \\
\text { percentage fee agreed to by parties }\end{array}$ \\
\hline
\end{tabular}

114. See Trevino v. H HL Fin. Servs., Inc., 945 P.2d 1345 (Colo. 1997); K uhn v. State, 924 P.2d 1053, 1057 (Colo. 1996).

115. See COLO. REV. STAT. § 13-17-203 ("If the plaintiffs prevail in any class action litigation brought against any public entity ... the amount of attorney fees which the plaintiffs' attorney is entitled to receive out of any award to the plaintiffs shall ... not exceed two hundred fifty thousand dollars....").

116. See Hernandez v. M onterey V illage A ssoc. L td. Partnership, 589 A.2d 888 n.3 (Conn. Ct. A pp. 1991) (endorsing the factors listed in J ohnson v. Georgia Highway Express, Inc., 488 F.2d 714, 717-19 (5th Cir. 1974)). A s stated by the Superior Court, those factors are the following: (1) the time and labor required; (2) the novelty and difficulty of the questions presented; (3) the skill required to perform the legal services; (4) the preclusion of other employment by the attorneys due to acceptance of the case; (5) the customary fee in the community; (6) whether the fee is fixed or contingent; (7) the time limitations imposed by client or circumstances; (8) the amount involved and the results obtained; (9) the experience, reputation, and ability of the attorneys; (10) the undesirability of the case; (11) the nature and length of the professional relationship with the client; and (12) awards in similar cases. See, e.g., H am v. G reene, N o. CV 91032275S, 1997 W L 255274, at*10 (Conn. Super. Ct. 1997).

117. See G oodrich v. E.F. H utton G roup, 681 A .2d 1039 (Del. 1996).

118. See, e.g., W einberger v. U O P, Inc., 517 A .2d 653, 654-55 (D el. Ch. 1986).

119. See Goodrich, 681 A .2d at 1039; Goodrich v. E.F. Hutton Group, Inc., No. 360 (1995), 1996 Del. LEXIS 73 (report of Chancellor A llen).

120. See K uhnlein v. D epartment of R evenue, 662 So. 2d 309 (Fla. 1995) (fee agreement between named plaintiffs and their attorneys in a common-fund class action cannot bind the remaining class members, so that court must use lodestar method to determine fees).

121. See Costello v. City of Cape Coral, 693 So. $2 d 48$ (Fla. D ist. Ct. A pp. 1997) (not a class case).

122. See Industrial D istrib. Group, Inc. v. Waite, 485 S.E.2d 792, 794 (Ga. 1997); State v. Private Truck Council of A m., Inc., 371 S.E.2d 378 (Ga. 1988).

123. See M ontalvo v. Chang, 641 P.2d 1321 (H aw. 1982).

124. See id.

125. See B rundidge v. G lendale F ed. Bank, 659 N .E.2d 909 (III. 1995).

126. See id.

127. See Citizens A ction Coalition of Ind., Inc. v. PSI Energy, Inc., 664 N.E.2d 401 (Ind. Ct. A pp. 1996) (dicta). 


\begin{tabular}{|c|c|c|}
\hline State & M ethod & Notes \\
\hline Kansas & Lodestar ${ }^{130}$ & $\begin{array}{l}\text { Common fund }{ }^{131} \text { lodestar modified by other } \\
\text { factors } s^{132} \text { and checked against percent of } \\
\text { recovery }{ }^{133}\end{array}$ \\
\hline Kentucky & Unsettled & R ecognizes common fund by statute ${ }^{134}$ \\
\hline Louisiana & Multi-factor ${ }^{135}$ & $\begin{array}{l}\text { R ecovery on quantum meruit basis, taking a } \\
\text { variety of factors into account }{ }^{136}\end{array}$ \\
\hline Maine & U nsettled & A ppears to reject common fund ${ }^{137}$ \\
\hline M aryland & M ulti-factor ${ }^{138}$ & \\
\hline M assachusetts & M ulti-factor ${ }^{139}$ & Common fund ${ }^{140}$ \\
\hline Michigan & L odestar $^{141}$ & Common fund only; no common benefit ${ }^{142}$ \\
\hline
\end{tabular}

128. See IOWA R. CIV. P. 42.16(e). This rule provides that "[i]n determining the amount of attorney's fees for a prevailing class the court shall consider the following factors: (1) [t]he time and effort expended by the attorney in the litigation, including the nature, extent, and quality of the services rendered; (2) [r]esults achieved and benefits conferred upon the class; (3) [t]he magnitude, complexity, and uniqueness of the litigation; (4) [t]he contingent nature of success; (5)[i]n cases awarding attorney's fees and litigation expenses [for litigation involving the] vindication of an important public interest, the economic impact on the party against whom the award is made; and (6) [a]ppropriate criteria in the I owa Code of Professional R esponsibility for Lawyers." I d.

129. See K ing v. A rmstrong, 518 N.W .2d 336 (I owa 1994) (approving a fee award of $50 \%$ of the recovery under I owa R ule of Civil Procedure 42.16(e) when class counsel had bargained at arms length for a contingency agreement with qualified class representative and case had low prospects of success).

130. See G igot v. Cities Serv. O il Co., 737 P.2d 18 (K an. 1987); A lison v. B oard of County Comm'rs, 737 P.2d 6 (K an. 1987).

131. See id.

132. The factors are those found in Shutts v. Phillips Petroleum Co., 679 P.2d 1159, 1164 (Kan. 1984), aff'd in part \& rev'd in part, 472 U.S. 797 (1985): (1) the number of hours spent on the case by the various attorneys and the manner in which they were spent; (2) the reasonable hourly rate for each attorney; ( 3 ) the contingent nature of success; (4) the extent, if any, to which the quality of an attorney's work mandates increasing or decreasing [the] amount to which the court has found the attorney reasonably entitled; (5) the amount involved in the class action; and (6) the benefit produced by the lawsuit.

133. See Gigot, 737 P. $2 d$ at 28 (noting that "in the normal range of common fund recoveries, common fee awards fall in the 20 to 30 percent range").

134. KY. REV. STA T. A NN. $\S 412.070$ provides for an allowance of fees and costs from a recovered fund "if one or more of ... the parties in interest has prosecuted for the benefit of others interested with him and has been to trouble and expense in that connection." See Commonwealth of Ky. R evenue Cabinet v. Herschel St. Ledger, 955 S.W.2d 539 (K y. Ct. A pp. 1997).

135. See White v. B oard of Trustees of the Teachers' R etirement Sys. of La., 276 So. $2 d 714$ ( $L$ a. Ct. A pp. 1973); In re Interstate Trust and Banking Co., 106 So. 2d 276 (La. 1958). The factors include "the extent and nature of the services rendered ... ; the labor, time, and trouble involved; the results achieved; the character and importance of the matter; the amount of money involved; the learning, skill, and experience exercised; and the difficulty of the legal problems." Id. at 282.

136. See id.

137. See Poussard, et al. v. Commercial Credit Plan, Inc. 479 A .2d 881, 883 (M e. 1984); Thiboutot v. State, 405 A .2d 230, 238 (M e. 1979), aff'd, 448 U .S. 1 (1980).

138. See, e.g., H ohensee v. M inear, 270 A .2d 776 (M d. 1970).

139. See Coggins v. New England Patriots Football Club, Inc., 550 N.E.2d 141 (Mass. 1990) (affirming trial court's discretionary award of fees out of common fund).

140. See Pearson v. B oard of H ealth, 525 N.E. $2 d$ 400, 402 n.3 (M ass. 1988).

141. See G rigg v. M ichigan Nat'l Bank, 274 N.W.2d 752, 770 (M ich. 1979) ("R easonableness of the fees would depend primarily upon the amount of time the attorneys spent on the case and upon the 


\begin{tabular}{|c|c|c|}
\hline State & $M$ ethod & Notes \\
\hline M innesota & $\begin{array}{l}\text { Lodestar or } \\
\text { Percentage }^{143}\end{array}$ & $\begin{array}{l}\text { In case with both monetary and non- } \\
\text { monetary relief, appeals court instructed } \\
\text { trial court to consider fees based on entire } \\
\text { value of settlement rather than only on value } \\
\text { of cash portion }{ }^{144}\end{array}$ \\
\hline M ississippi & U nsettled & $\begin{array}{l}\text { R ecognizes common fund by statute; }{ }^{145} \text { not } \\
\text { for private attorney general suits }{ }^{146}\end{array}$ \\
\hline Missouri & M ulti-F actor ${ }^{147}$ & $\begin{array}{l}\text { Trial court has discretion to award fees } \\
\text { based on percent of recovery }{ }^{148}\end{array}$ \\
\hline M ontana & U nsettled & Common fund $^{149}$ \\
\hline Nebraska & U nsettled & $\begin{array}{l}\text { Common fund, but not common benefit } \\
\text { recovery }\end{array}$ \\
\hline Nevada & U nsettled & $\begin{array}{l}\text { Court recognizes both common fund and } \\
\text { common benefit rules in dicta }\end{array}$ \\
\hline $\begin{array}{l}\text { N ew H amp- } \\
\text { shire }\end{array}$ & U nsettled & Common benefit recovery ${ }^{152}$ \\
\hline New J ersey & Multi-factor ${ }^{153}$ & $\begin{array}{l}\text { E arly case recognizes common fund } \\
\text { doctrine; }{ }^{154} \text { court recognizes contingency } \\
\text { enhancement for lodestar awards under } \\
\text { fee-shifting statutes }{ }^{155}\end{array}$ \\
\hline
\end{tabular}

nature and extent of the benefit conferred upon the intervening class members. Such a fee, plus costs, would be payable from the proceeds of the judgment prior to computation for distribution.").

142. See D ozier v. A utomobile Club of M ich., 244 N.W .2d 376 (M ich. Ct. A pp. 1976).

143. See H eller v. Schwan's Sales E nter., I nc., 548 N.W .2d 287 (M inn. Ct. A pp. 1996) (holding that award of one-sixth of the recovery was appropriate in a common fund case).

144. See Hawkins v. Thorp Loan and Thrift Company, No. C3-91-1705, 1991 M inn. A pp. LEXIS 1257.

145. MISS. CODE A NN. § 11-53-37 (1997) provides that "[w] for the benefit of himself and all others similarly situated, and thereby there is in such suit recovered or preserved property or a fund for the common benefit, the chancery court may make an allowance to such party of the reasonable costs incurred, which costs shall include the necessary disbursements, and reasonable solicitor's fees, out of the property recovered or preserved for the common benefit."

146. See Fordice v. Thomas, 649 So. $2 d 835$ (M iss. 1995).

147. See J esser v. M ayfair H otel, Inc., 360 S.W.2d 652 (M o. 1962). In determining the reasonable value of legal services, the trial court is instructed to consider the time spent, nature and character of services rendered, nature and importance of the subject matter, degree of responsibility imposed on the attorney, value of property or money involved, degree of professional ability required and the result. See In Re A Icolac, Inc. Litig., 945 S.W .2d 459, 461 (M o. Ct. A pp. 1997) (citing U nion Center R edev. Corp. v. Leslie, 733 S.W.2d 6, 9 (M o. Ct. A pp. 1987)).

148. See In re A Icolac, 945 S.W.2d at 461; Senn v. M anchester Bank of St. Louis, 583 S.W .2d 119, 138 (M o. 1979) (assuming that class counsel in common fund case would be paid on a percentage basis).

149. See M urer v. State Compensation M ut. Ins. Fund, 942 P.2d 69 (M ont. 1997); M eans v. M ontana Power C 0., 625 P.2d 32 (M ont. 1981).

150. See D ennis v. State, 451 N.W .2d 676 (N eb. 1990), rev'd on other grounds, 498 U .S. 439 (1991).

151. See G uild, Hagen \& Clark, L td. v. First Nat'I B ank of N ev., 600 P.2d 238 (N ev. 1979).

152. See M ooney v. City of Laconia, 573 A .2d 447 (N.H. 1990). 


\begin{tabular}{|c|c|c|}
\hline State & M ethod & Notes \\
\hline New M exico & U nsettled & \\
\hline New Y ork & Lodestar ${ }^{156}$ & $\begin{array}{l}\text { Statute permits courts in class action cases to } \\
\text { award fees based on reasonable value of } \\
\text { legal services rendered }{ }^{157}\end{array}$ \\
\hline North Carolina & Unsettled & Common fund ${ }^{158}$ \\
\hline North D akota & Percentage $^{159}$ & Lodestar not mentioned. \\
\hline O hio & $\begin{array}{l}\text { Lodestar or } \\
\text { Percentage }{ }^{160}\end{array}$ & \\
\hline Oklahoma & Unsettled & $\begin{array}{l}\text { Court recognizes both common fund and } \\
\text { common benefit rules in dicta. }{ }^{161}\end{array}$ \\
\hline Oregon & Multi-factor $r^{162}$ & $\begin{array}{l}\text { Civil Procedure rule allows courts to award } \\
\text { attorneys fees but does not establish } \\
\text { procedure for doing so }{ }^{163}\end{array}$ \\
\hline Pennsylvania & M ulti-factor ${ }^{164}$ & $\begin{array}{l}\text { Recognizes common fund by statute }{ }^{165} \text { court } \\
\text { declines to award fees on private attorney } \\
\text { general theor } y^{166}\end{array}$ \\
\hline
\end{tabular}

153. N.J. RULE OF PROFESSIONA L CONDUCT 1.5(a) provides that "[a] lawyer's fee shall be reasonable. The factors to be considered in determining the reasonableness of a fee include the following: (1) the time and labor required, the novelty and difficulty of the questions involved, and the skill requisite to perform the legal service properly; (2) the likelihood, if apparent to the client, that the acceptance of the particular employment will preclude other employment by the lawyer; (3) the fee customarily charged in the locality for similar legal services; (4) the amount involved and the results obtained; (5) the time limitations imposed by the client or by the circumstances; (6) the nature and length of the professional relationship with the client; (7) the experience, reputation, and ability of the lawyer or lawyers performing the services; (8) whether the fee is fixed or contingent." But cf. Incollingo v. Canuso, 687 A.2d 778 (N.J. Super. Ct. A pp. Div. 1997) (disapproving use of factor analysis in statutory feeshifting cases).

154. See Sarner v. Sarner, 185 A .2d 851 (N.J . 1962).

155. See R endine v. Lorestani, 661 A .2d 1202, 1231 (N.J . 1995).

156. See, e.g., Becker v. Empire of A merica Fed. Sav. Bank, 577 N.Y .S.2d 1001 (N.Y. A pp. Div. 1991) (holding that court must first consider the number of hours reasonably expended from contemporaneous time sheets); E stuch v. V olkswagen A G, 578 N.Y .S.2d 306 (N.Y . A pp. D iv. 1991); M atter of R ahmey v. Blum, 466 N.Y .S.2d 350, 356-57 (N.Y. A pp. D iv. 1982).

157. N.Y. CIVIL PRACTICE LAW AND RULES § 909: "[i]f a judgment in an action maintained as a class action is rendered in favor of the class, the court in its discretion may award attorneys' fees to the representatives of the class based on the reasonable value of legal services rendered and if justice requires, allow recovery of the amount awarded from the opponent of the class."

158. See Faulkenbury v. Teachers' \& State Employees R etirement Sys. of North Carolina, 483 S.E.2d 422 (N.C. 1997).

159. See Horst V. Guy, 211 N.W.2d 723 (N.D. 1973) (approving as proper an award of $25 \%$ of the recovery).

160. See Steiner v. Van D orn Co., 660 N.E.2d 1256 (O hio Ct. A pp. 1995) (shareholders derivative case).

161. See City Nat. B ank \& Trust C 0. v. O wens, 565 P.2d 4 (O kla. 1977).

162. See Kalman v. R obert C urry, W ater F ront R ecreation, Inc., 745 P.2d 1232 (O r. Ct. A pp. 1987).

163. See OR. R. CIV.P. 32N (in setting a fee in a class action, court is to consider the following factors: the time and effort expended by the attorney in the litigation, including the nature, extent, and quality of the services rendered; the results achieved and benefits conferred upon the class; the magnitude, complexity, and uniqueness of the litigation; the contingent nature of success; and appropriate criteria in the Oregon Code of Professional Responsibility). 


\begin{tabular}{|c|c|c|}
\hline State & M ethod & Notes \\
\hline R hode I sland & Unsettled & Common fund doctrine. ${ }^{167}$ \\
\hline South Carolina & U nsettled & \\
\hline South D akota & U nsettled & $\begin{array}{l}\text { Common fund, but common benefit rejected } \\
\text { at least in suits against state }{ }^{168}\end{array}$ \\
\hline Tennessee & M ulti-factor ${ }^{169}$ & Courts expressly reject lodestar \\
\hline Texas & $\begin{array}{l}\text { L odestar or } \\
\text { Percentage }^{170}\end{array}$ & $\begin{array}{l}\text { Trial courts are instructed to test percentage } \\
\text { fee against lodestar in non-monetary } \\
\text { settlement cases in order "to prevent grossly } \\
\text { excessive attorney's fee awards and to } \\
\text { minimize the inherent conflict between class } \\
\text { counsel and the class members" }\end{array}$ \\
\hline U tah & Multi-factor ${ }^{172}$ & $\begin{array}{l}\text { Recent decision suggested that stipulation of } \\
\text { settlement using percentage of recover may } \\
\text { be permissible }^{173}\end{array}$ \\
\hline Vermont & U nsettled & $\begin{array}{l}\text { H as not yet accepted common fund } \\
\text { recoveries and declined opportunity to do so } \\
\text { in } 1993^{174}\end{array}$ \\
\hline Virginia & U nsettled & \\
\hline
\end{tabular}

164. See J ones v. M uir, 515 A .2d 855 (Pa. 1986); PA. R. CIV. P. 1716 ("In all cases where the court is authorized under applicable law to fix the amount of counsel fees it shall consider, among other things, the following factors: (1) the time and effort reasonably expended by the attorney in the litigation; (2) the quality of the services rendered; (3) the results achieved and benefits conferred upon the class or upon the public; (4) the magnitude, complexity and uniqueness of the litigation; and (5) whether the receipt of a fee was contingent on success. Note: The rule does not determine when fees may be awarded. That is a matter of substantive law. The order in which the factors are listed is not intended to indicate the priority or weight to be accorded them respectively.").

165. See 42 PA. CODE § 2503(8) (1997) ("The following participants shall be entitled to a reasonable counsel fee as part of the taxable costs of the matter: ... [a]ny participant who is awarded counsel fees out of a fund within the jurisdiction of the court pursuant to any general rule relating to an award of counsel fees from a fund within the jurisdiction of the court." ).

166. See ones v. Muir, 515 A .2d 855 (Pa. 1986).

167. See M alinou v. Powers, 333 A .2d 420 (R.I . 1975).

168. See V an E mmerik v. M ontana D akota U til. Co., 332 N.W .2d 279 (S.D.), cert. denied, 464 U .S. 915 (1983).

169. See U nited Med. Corp. v. Hohenwald Bank, 703 S.W.2d 133, 137 (Tenn. 1986) (not a class case) (applying standards of D R 2-106); H obson v. First State Bank, 801 S.W.2d 807 (Tenn. Ct. A pp. 1990) (recognizing common fund doctrine).

170. See G eneral M otors Corp. v. Bloyed, 916 S.W.2d 949 (Tex. 1996).

171. See id. at 961.

172. The leading case is Plumb v. State of Utah, 809 P.2d 734 (Utah 1990), in which the Supreme Court of U tah upheld a trial court's use of the lodestar approach in a common fund case as not an abuse of discretion, but observed that the trial court had weighed the lodestar results along with other factors, including a review of R ule 1.5 of the R ules of Professional Conduct, the settlement agreement, state legislation, the report of a special master, and the percentage of the total common fund to be used for class counsel fees.

173. The $U$ tah Supreme Court approved a stipulation of settlement awarding approximately $20 \%$ of the recovery, a result suggesting that percentage settlements may be acceptable in appropriate cases. See id.

174. See R obes v. Town of H artford, 636 A .2d 342 (V t. 1993). 


\begin{tabular}{|c|c|c|}
\hline State & M ethod & Notes \\
\hline Washington & Percentage $\mathrm{e}^{175}$ & $\begin{array}{l}\text { Court notes percentages are "often in the } \\
\text { range of } 20 \text { to } 30 \text { percent", and that under } \\
\text { "special circumstances," percentage can be } \\
\text { replaced by lodestar"176 }\end{array}$ \\
\hline West $V$ irginia & M ulti-factor ${ }^{177}$ & \\
\hline Wisconsin & $\begin{array}{l}\text { Lodestar or } \\
\text { Percentage }\end{array}$ & Common fund in $1997^{179}$ \\
\hline Wyoming & Lodestar ${ }^{180}$ & $\begin{array}{l}\text { A dopts multifactor test of D R 2-106 by } \\
\text { statute, }{ }^{181} \text { but Supreme Court endorses } \\
\text { lodestar, viewing it as equivalent }{ }^{182}\end{array}$ \\
\hline
\end{tabular}

175. See B owles v. Washington D ep't of R etirement Sys., 847 P.2d 440 (Wash. 1993).

176. Id. at $450,451$.

177. See A etna Cas. \& Sur. Co. v. Pitrolo, 342 S.E.2d 156, 162 (W. Va. 1986) (not a class case) (reasonableness of the fee sought against a third party is generally to be determined based on factors such as (1) the time and labor required; (2) the novelty and difficulty of the questions; (3) the skill requisite to perform the legal service properly; (4) the preclusion of other employment by the attorney due to acceptance of the case; (5) the customary fee; (6) whether the fee is fixed or contingent; (7) time imitations imposed by the client or the circumstances; (8) the amount involved and the results obtained; (9) the experience, reputation, and ability of the attorneys; (10) the undesirability of the case; (11) the nature and length of the professional relationship with the client; and (12) awards in similar cases.)

178. See Wisconsin Retired Teachers A ss'n v. Employe [sic] Trust Funds Board, 558 N.W.2d 83 (W is. 1997). In addition, the court is required to consider: "the time and labor required, the novelty and difficulty of the question presented by the case, the skill requisite to perform the legal service properly, the preclusion of other employment by the attorneys due to acceptance of the case, the customary fee, whether the fee is fixed or contingent, any time limitation imposed by the client or the circumstances, the amount involved and the results obtained, the experience, reputation and ability [of] the attorney, the undesirability of the case, the nature and length of the professional relationship with the client, and awards in similar cases." Id. at 99.

179. See id.

180. See M CL ain v. A nderson, 933 P.2d 468 (Wyo. 1997) (not a class case).

181. See J ohnston v. Stephenson, 938 P.2d 861, 863 (Wyo. 1997) (not a class case) (citing Wro. STA T. A NN. \& 1-14-126(b)).

182. See Pekas v. Thompson, 903 P.2d 532 (Wyo. 1995). 
A PPENDIX B

REBATE FORM 